This work was supported by the US Department of Energy; Assistant Secretary for Environment, Division of Environmental Safety and Engineering.

This report was prepared as an account of work sponsored by an ayency of the United States Government. Neither the United States Governument nor any agency thereor, nor any of their employees, makes any warnanty, expres or implied;' or asumes any legal linbility or responsibility for the accuracy, completenes, or usefuloesc of any information, apperatus, product, or proces discloced, or represents that its use would not infinie privately owned rights. References hesein to wh specific commerciel product, process, or service by trade name, traderrark, mumfecturer, or othenwie, does not neceswariby conatitute or inply its

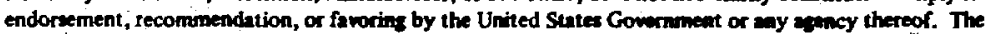
views and opiations of authors expremed wercin do not ancemerily stexe or refloct thene of the United States Coverwinent or any apency thereof. 


\title{
Evaluation of Research and Development for Terminal Isolation of Nuclear Wastes
}

\author{
Barry W. Burton
}

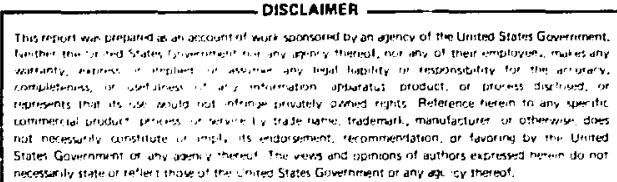




\title{
EVALUATION OF RESEARCH AND DEVELOPMENT FOR TERMINAL ISOLATION OF NUCLEAR WASTES
}

\author{
by \\ Barry W. Burton
}

\begin{abstract}
The National Waste Terminal Storage program is responsible for identifying and constructing a geologic repository for spent reactor fuel, high-level waste, and transuranic waste. Extensive research and development work is in progress in the areas of site selection, waste treatment and waste form development, model development and validation, and long-term repository performance assessment. Many potential technologies are under investigation, but specific tcchnologies cannot be identified until a repository site is selected. It is too early in the program to assess the adequacy of environmental control technologies for deep geologic disposal.
\end{abstract}

\section{INTRODUCTION}

In Octobur 1979 the Los Alamos Scientific Laboratory began a program to assist the Environmental and Safety Engineering Division (ESED) to conduct an independent evaluation of the environmental control technologies applied to nuclear waste management and to advise ESED where these controls seem to be inadequate or where further studies are needed to determine adequacy. In November 1980 we submitted a draft report "Overview Assessment of Nuclear Waste Management" describing the general practices used to manage nuclear fuel cycle wastes. This topical report discusses research and development activities for terminal isolation of spent fuel, high-level waste (HLW), and transuranic (TRU) waste in geologic repositories.

The National Waste Terminal Storage (NWTS) program provides the research and development activities to identify repository sites and to develop the technology for repository design, licensing, and operation. Potential repository sites will be characterized in several different geologic media, from which one may be chosen as the first regional repository. The first facility is anticipated to be operational by the mid-1990s. The organization of the NWTS program is shown in Fig. 1.
That part of the NWTS program concerned with mined repositories in geologic formations is managed by the Office of Nuclear Waste Isolation (ONWI), directed by the Battelie Memorial Institute. This organization is responsible for developing the generic technology for repositories in salt and other geologic environments and for conducting characterization activities on non-Department of Energy (DOE) lands.

Site selection strategy is based on a three-stage identification process of regional, areal, and site-specific studies. At each stage all available data are reviewed to ensure that each area has been adequately investigated at that level and to identify deficiencies in the data base. New screening methods, based on multiple barrier and geohydrologic principles, are being developed.

The Basalt Waste Jsolation Project (BWIP) is responsible for determining the suitability of basalt (particularly at the Hanford site) as a repository medium. The Nevada Nuclear Waste Storage Investigations (NNWSI) program is evaluating the Nevada Test Site (NTS) and southern Nevada as a potential repository site.

Many programs are conducting research and development activities for site screening and selection, waste treatment and waste form development, ga hydrologic modeling. and in situ testing of generic rock types and at 


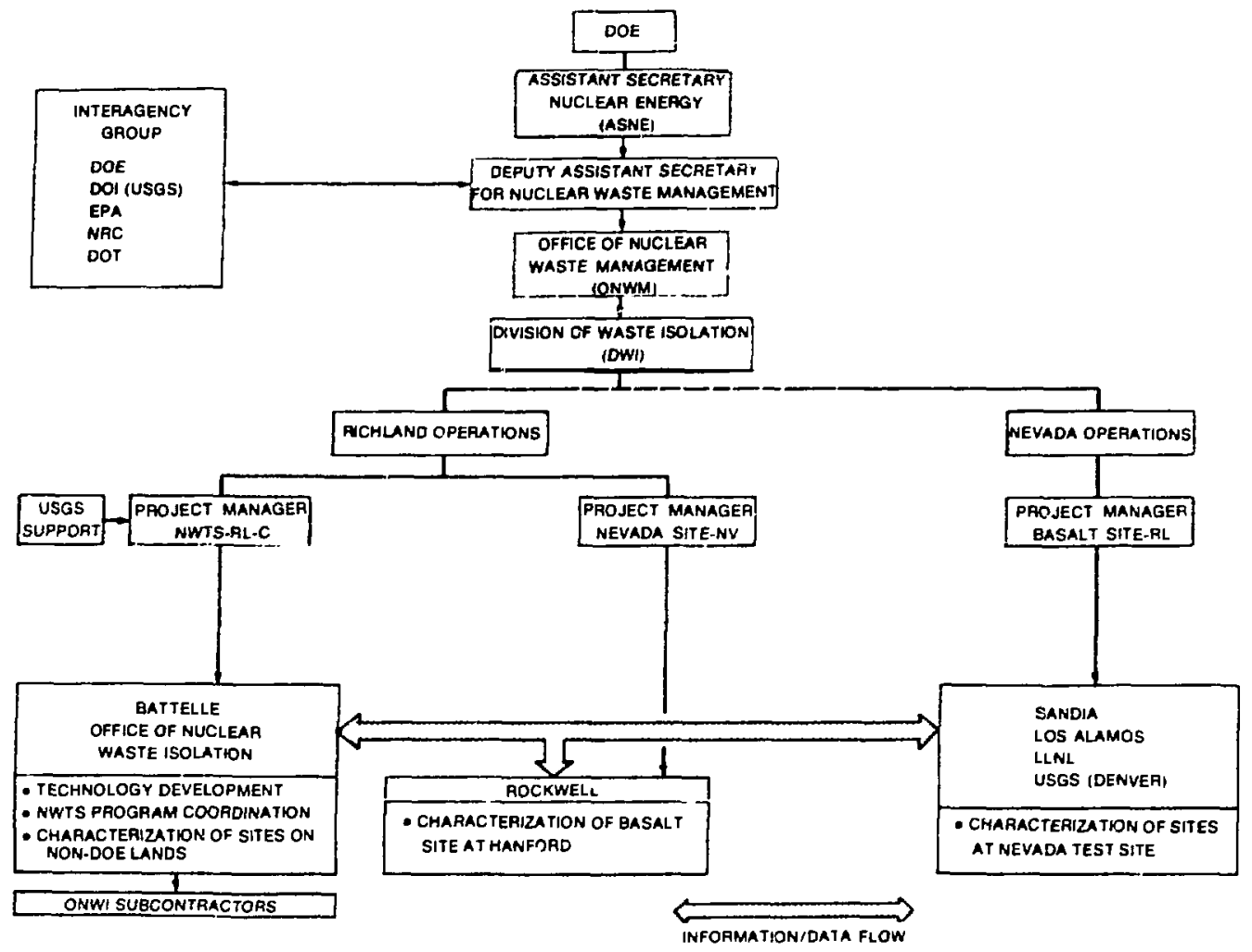

Fig. I. National Waste Terminal Storage Program.

specific candidate sites. These programs will be discussed and, as far as possible, the responsible organizations will be identified.

\section{SITE SELECTION}

The selection of a candidate repository site involves characterizing promising areas in the United States. Factors that must be considered in selecting and qualifying an acceptable site are listed in Table I. Specific requirements based on these general factors have been proposed and will be used until the Nuclear Regulatory Commission (NRC) and the Environmental Protection Agency (EPA) establish formal licensing criteria [ONWI-33(2), 1980]. Much of the necessary information for site selection is available, including topography, seismic and yolcanic potential for some areas, regional hydrology, and resource potential (DOE/EIS-0046F, 1980), though data are not complete for many areas.
Data on the depth to a potential emplacement zone, lateral extent and attitude of rock types, and the characteristics of surrounding formations must by determined on a site-by-site basis. The Office of Nuclear

TABLE I

\section{SITE QUALIFICATION CRITERIA}

Site geometry

Tectonic environment

Subsurface hydrology and geochemistry

Surface hydrology

Geologic characteristics

Surface characteristics

Potential for human intrusion

Proximity to population centers

Environment

Social, political. and economic factors

${ }^{a}$ From Newcomb \& Waite (1979). 
Waste Isolation (ONWI) is responsible for developing criteria for disposing of radioactive wastes and site qualification criteria: Lawrence Livermore National Laboratory (LLNL) is assisting in deriving paramcters for site evaluation. Both LLNL and Sandia National Laboratory (SNL) are developing flow charts to organize the evaluation procedure for candidate sites.

\section{A. Long-Term Geologic Stability}

The ability of a repository to effectively contain spent fuel or HLW for many thousands of years depends heavily on the long-term stability of the site. The major factors in geologic stability are tectonic uplift and subsidence. seismicity, and volcanic activity.

Part of the regional studies conducted by ONWI is to identify areas of high tectonic, seismic. and volcanic activity and exclude them from further consideration. This involves an extensive preliminary literature search of all geologic information about the area, followed by increasingly more detailed investigations of areas of decreasia:s size. LLNL has compiled for NRC a geoscience data base handbook containing reference information on factors that must be considered in analyz. ing or modeling a proposed repository (Isherwood, 1981). Field studies to support site selection activities include geophysical and hydrologic investigations. Regional and areal studies are being conducted by Woodward-Clyde Consultants in the Paradox Basin; the Texas Bureau of Economic Geology and SNL for the West Texas bedded salt: Law Engineering for the Gulf Coast salt domes: Stone and Webster in the Salina Basin; the U.S. Geological Survey (USGS). Los Alamos National Laboratory. and SNL at the Nevada Test Site: Rockwell Hanford Operations (RHO). Pacific Northwest Laboratory (PNL), and others in the Columbia Plateau; and the USGS and SNL in the Permian Basin. The USGS is also engaged in predicting the probabilities of long-term events and changes, and Los Alamos and SNL personnel are studying the potential for future volcanic activity in the southern Nevada region. Release scenario modeling is being conducted by the Waste Isolation Performance Assessment Program (WIPAP) at PNL.

\section{B. Characterization of Geology and Hydrology}

Data on the subsurface environment are needed to assess the stratigraphic and structural relationships at a potential repository site. Geophysical data are in- terpreted to define the models that will be used to assess the geologic, geochemical. thermal, mechanical, and hydrologic characteristics. These data are obtained by seismic. magnetic. electric. gravity, and recently, radar surveys. Well logging and downhole geophysical techniques are included.

The USGS is developing and improving instrumentation and techniques for geophysical investigations, including radar and high-frequency electromagnetic borehole techniques. LLNL and Texas A\&M University are also involved in developing radar exploration techniques. The Texas Bureau of Mines and Continental Oil Company are improving existing geophysical techniques. Field evaluations of geophysical techniques are being conducted by Lawrence Berkeley Laboratory (LBL) at Stripa, Sweden and at a University of Arizona field site. Methods to apply geothermometry to site evaluation are under study at the Georgia Institute of Technology. Brookhaven National Laboratory (BNL) is developing methods to apply geothermometry to the study of shale. Oak Ridge Operations (ORO) is Involved in evaluating the application of petroleum exploration data to identify structural features in salt anticlines. SNL is investigating the effect of depth on earthquake ground motion and Savannah River Laboratory (SRL) is studying subsurface earthquake danage.

Ground water is generally considered to be the primary medium for radionuclide migration to the biosphere. The principles that control fluid flow through geologic media are well known. The characteristics of major aquifers have been extensively studied, though much work is sill needed to define regional and local flow systems (DOE/EIS-0046F, 1980). Hydrologic studies involve (1) regional 2-dimensional modeling; (2) 3dimensional hydrologic characteristics at candidate sites: and (3) the possible effects of the repository, climate. and other factors on the local ground water system.

The USGS is extensively involved in hydrologic studies, including water flux in the unsaturated zone of deserts. field tests of flow in unsaturated alluvium, nonisothermal water fluxes in the unsaturated zone. characterization of local ground water systems. shortterm hydraulic effects, fluid flow in fractured rocks, and modeling of transport in the unsaturated zone (DOE/EIS-0046F, 1980). LBL is studying fluid flow through fractures in crystalline rock and LLNL is investigating the fracture permeability of various rocks under pressure. 


\section{Site Investigations}

In 1957 the National Academy of Sciences (NAS) issued a report recommending that radioactive wastes be isolated in deep geologic formations and concluding that salt is the most suitable medium (NAS. 1957). Since that time most site investigations have been directed toward salt and the NWTS program has only recently been expanded to include potential media other than salt. Thus more detailed knowledge has been obtained regarding this medium than any other. Major areas under investigation are shown in Fig. 2.

\section{Salt Basins}

a. Gulf Coast Salt Domes. Evaluation of the salt domes of Texas. Louisiana. and Mississippi was begun by the USGS in 1963. Of the 36 potential sites identified, eight have been selected for further study. Law Engineering is the geologic project manager for DOE, assisted by ONWI, the USGS, Louisiana State University, the University of Southern Mississippi, and the Texas Bureau of Economic Geology (Durham, 1979). Investiga- tions of the Palestine Dome led to its elimination in 1979 (Kreitler, 1979; Patchick, 1980) and two or three should be selected soon for local studies. The USGS is conducting regional ground water studies in salt dome basins in northern Louisiana and in Mississippi (Hosman, 1979; Spiers, 1979). A major in situ testing facility in a salt dome at Avery Island, Louisiana will be discussed in Section IV-B.

b. Paradox Basin. Evaluation of the bedded salt formations in the Paradox Basin. Utah was begun by the USGS in 1972. Currently, the primary responsibility for identifying sites lies with Woodward-Clyde Consultants: the USGS is continuing to characterize the regional hydrology. The existing data base is not yet complete enough for a full assessment of all the individual parts of the region. Continuing investigations are directed toward determining the Quaternary history, current seismicity, and the hydrologic and chemical characteristics of the regional ground water flow system (DOE/NE-0007, 1980). The regional reconnaissance is now compiete and four areas have been identified for further study. These are Salt Valley, Gibson Dome, Elk Ridge, and Lisbon Valley. Current investigations at these sites include

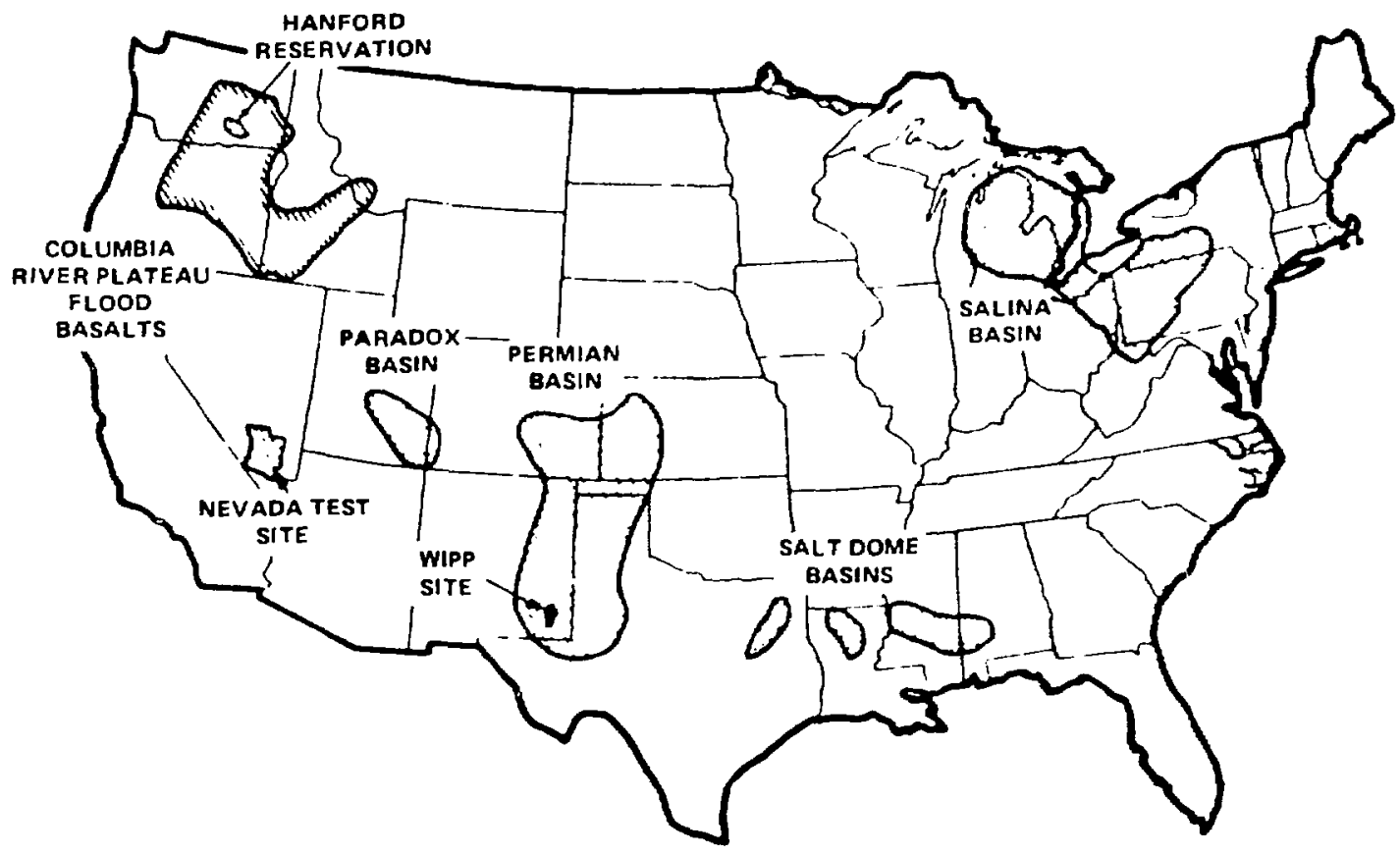

Fig. 2. Regions studied or now under ct!ndy for possible terminal storage of radioactive wastes. 
drilling and surface electromagnetic surveys at Gibson Dome and Elk Ridge, and seismic reflection surveys at Elk Ridge. Potential resource conflict and ground water flow system evaluations are in progress (DOE/NE-0007, 1980).

c. Salina Basin. The Salina Basin is located in parts of Michigan, Ohio, Pennsylvania, and New York. A regional reconnaissance study has been completed in the New York and Ohio portions of the basin by Stone and Webster Engineering Corporation and several areas have been identified for further study (DOE/NE-0008, 1980). Data on the Michigan part of the basin are insufficient to allow selection of study areas (DOE/NE-0007, 1980). No field studies have been performed for DOE, though some work has been done by the USGS. A considerable amount of information on the Salina Basin is still required, including deep ground water circulation and flow systems, detailed composition of the salt beds, water content and mineral impuritics in the salt, the nature of facies changes within salt beds and the surrounding rocks, the rate and processes of salt dissclutioning, and oil and gas potential (DOE/NE-0007, 1980). At the present time no additional field work in the Salina Basin is planned (Norris. 1979; Peck et al., 1979).

d. Permian Basin. The Permian Basin in Colorado, Kansas, Oklahoma, Texas, and New Mexico actually consists of several subbasins. The USGS began studies in 1972 and much of the region is fairly well characterized. Areas in the Palo Duro and Dalhart subbasins have been identified for further studies and some field work is being done to establish a baseline to calibrate existing data (DOE/NE-0008, 1980). These detailed site studies, begun in 1980, are directed primarily toward characterizing the geology, tectonics, hydrology, and resource potential of the subbasins (DOE/NE-0007, 1980). The bedded salt basins in West Texas are being evaluated by the Texas Bureau of Economic Geology; SNL is investigating the climatic and tectonic stability of this area.

e. Waste Isolation Pilot Plant. Characterization of the Waste 1solation Pilot Plant (WIPP) site in southeastern New Mexico was begun in 1974 by SNL. The facility was envisioned to receive defense TRU waste and to provide experimentai test capability for HLW. Following the recommendations of the Interagency Review Group (Deutch, 1979), President Carter cancelled the WIPP and the site consideration responsibility was transferred to ONWI. In January 1981 the WIPP was restored to the Defense Program and site development is expected to proceed as originally planned (Federal Register. 1981). A geologic characterization report. an environmental impact statement. and a draft safety analysis report for the site have been issued (Powers et al.. 1978: DOE/EIS 0026. 1980: DOE/NE-0008. 1980). Although this site is no longer available for consideration as a commercial spent fuel or HLW repository, site validation studies and experimental programs at the WIPP should provide valuable information on repository performance in bedded salt.

\section{Areas Underlain by Rocks Other Than Salt}

Before 1979, site investigation activities were primarily directed toward salt (both bedded and dome salt). In that year the NWTS program was expanded to include rocks other than salt. These include plutonic rocks. basait. tuff. shale. and argillite.

Screening of the areas is based on consideration of the various geohydrologic environments. A nationwide literature search will be used to compile a computerized data base to aid the investigation process. The USGS is planning an evaluation of geohydrologic provinces in the United States, as well as conducting surveys of granite and other crystalline rocks, western Cretaceous shales, tuff. and zeolitized tuff.

a. Basalt Waste Isolation Project. Site selection studies of the Columbia Plateau are expected to be completed in 1981 (Deju. 1979). Site A-H. west of the 200 West Area low-level (LLW') waste burial site. has been chosen by a committee of RHO and WoodwardClyde personnel as the primary candidate site. An alternate. Site J. is east of the 200 East Area Area (Meyers. 1980). Both sites are in the Cold Creek Syncline area of the Pasco Basin. on the Hanford Site. Gcophysical sudies are now underway at Site A-H.

Geologic and hydrologic investigations began in 1977 as a continuation of work that was conducted from 1968 to 1972. These studies include detailed geologic and hydrologic investigations of the Wanapum and Grande Ronde Basalts and should be completed in 2 to $3 \mathrm{yr}$ (Long. 1979: DOE/NE-0008, 1980; Teague. 1980). In the Pasco Basin more than 54 line-km of seismic reflection survey stations have been established, and $3200 \mathrm{~km}^{2}$ of multi-level, high-resolution aeromagnetic surveys have been completed (Edwards, 1980). Intraflow structural relationships of the Untanum Basalt, in which a repository would likely be sited. have been refined (Curran. 1980). 
Bibliographies of geologic data regarding the Columbia Plateau have been updated and surface geologic maps have been compiled to assess the tectonic history of the area, including satellite imagery and aerial photographs (Price, 1980). The geologic integration report for the BWIP is completed (Meyers et al., 1979).

The Near-Surface Test Facility (NSTF) has been established to demonstrate handling, placement, storage, and retrieval of nuclear waste in basalt. The NSTF is discussed in Section IV-B. A shallow borehole plugging test in basalt will be discussed in Section IV-C. Kaiser Engineers, Inc.. Parsons Brinckerhofr Quade, and Douglas, Inc., are jointly developing the conceptual design for a repository in basalt (Deju, 1979; Curran, 1980; Turner, 1980).

b. Nevada Test Site and Southern Nevada. The evaluation of NTS and southern Nevada is managed by Nevada Operations (NVO) and conducted by the USGS, SNL, LLNL, and Los Alamos National Laboratory for the Nevada Nuclear Waste Storage Investigations (NNWSI) (Lincolin, 1979). Potential sites at NTS are limited to the southwestern part to avoid interference with weapons tesing activities. Several site evaluation studies have been conducted in granite. argillite, and tuff. All the sites.except the tuff at Yucca Mountain. have been rejected.

Field studies at Yucca Mountain have included seismic and volcanic hazard studies. geologic mapping. and core and geophysical drilling to assess the extent of favorable geologic relationships (DOE/NE-0008, 1980; Johnstone and Wolfsberg, 1980: Crowe, 1980). An ideal repository in tuff would be in a thermally conductive, mechanically strong welded tuff enveloped by a lowpermeability, highly sorptive zeolitized tuff (Johnstone and Wolfsberg, 1980). Field tests at the Climax Spent Fuel Facility are designed to simulate repository operation in granite (see Section IV-B). Experiments at GTunnel are providing information regarding the effects of water on the thermomechanical response of tuff. These experiments include laboratory studies, in situ heater tests, and computer modeling. In-field radionuclide migration studies at G-Tunnel and laboratory sorption tests are underway (Wolfsberg, et al., 1979; Vine, et al., 1980; Cirowe and Wolfsberg, 1980; Crowe, 1980). The 3.5- to 4-yr program, involving SNL, Los Alamos, and Argonne National Laboratory (ANL), is studying nuclide migration through a single fracture. The program consists of two separate experiments: one using stable nuclides and the other using actinides (Johnstone and Wolfsberg,
1980). Los Alamos is also studying migration of radionuclides through alluvium at a 1965 underground weapons test site (Hoffman et al., 1977: Wolfsberg. 1978).

Current work is directed toward identifying structural features that affected the distribution of past volcanism. A 2-dimensional finite difference model for regional hydrologic flow is being tested. An additional $1800 \mathrm{~m}$ of core and hydrologic test holes are being drilled to correlate with a $760-\mathrm{m}$ previous hole (Johnstone and Wolfsberg. 1980).

The Mine Design Working Group, with representatives from SNL, Los Alamos, RE/SPEC, Inc.. and Texas A\&M University, is identifying model needs and critical data needs to develop conceptual test plans for in situ experiments, to define a repository environment in tuff, and to integrate the results into a data base for a conceptual repository design (Johnstone and Wolfsberg. 1980).

c. Other Areas Under Study. The evaluation of argillaceous basins in the United States is being conducted primarily by the USGS, Oak Ridge National Laboratory (ORNL), and Earth Resources Associates (Gonzales and Johnson, 1979; Brunton, 1979). The initial literature search and regional assessment were completed in 1980; laboratory testing on rock properties is expected to continue through 1981. Different types of argillaceous rocks being studied include those containing carbonaceous material, those lacking carbonaceous material and with little or no hydrous expanding clays, and those with smectite as the major clay constituent.

Savannah River Laboratory (SRL), Kentucky Liniversity, North Carolina University, and Dames \& Moore are evaluating several regions in the eastern United States: (1) the Piedmont Province (igneous and metamorphic rocks), (2) Triassic basins (mudstones, shales, sandstones, and metamorphics), and (3) the Coastal Plains (semiconsolidated sandstones, clays. and limestones) (Spiers, 1979). Studies of nineral and chemical alterations during diagenesis and low-grade metamorphism of shales and other clay-rich rocks are being performed by the Georgia Institute of Technology (DOE/NE-0007, 1980). They are also developing geothermometry methods to determine the thermal history of shales at 100 to $400^{\circ} \mathrm{C}$ (Weaver, 1979).

The USGS and Dames $\&$ Moore are investigating the suitability of various crystalline intrusives throughout the country (Murrie and Gates. 1979; DOE/EIS-0046F, 1980). 


\section{WASTE TREATMENT AND WASTE FORM DEVELOPMENT}

\section{A. Waste Treatment Technology}

A large program is underway to develop the technologies necessary for waste pretreatment, to produce waste forms suitable for disposal, and to demonstrate these technologies through pilot plant facilities. The lead oflice for this effort is Savannah River Operations (SRO) with SRL providing technical assistance. Process development includes spray calciner/in-can melting, nuidized bed calciner/continuous melting, direct liquid-bed continuous melting, fluidized bed calcination, and various conibinations of these. In addition, alternate waste form production and waste form quality verification studies are being conducted at many laboratories and by their contractors. Waste materials needs and evaluation are coordinated for the entire Waste Management Program by the Waste Management Steering Committee.

TRU waste treatment technology development is directed by Albuquerque Operations Office (ALO) with technical assistance from Rockwell International at Rocky Flats. Their objective is to develop and demonstrate solid waste treatment methods for TRU wastes to meet Federal repository acceptance criteria. In 1978 , testing began on three prototype TRU-contaminated solid waste treatment systems: (1) controlled air incineration, (2) fluidized bed incineration, and (3) acid digestion. A pilot scale test of electropolishing for decontaminating metal surfaces is now in operation.

Various DOE laboratories are involved in the waste treatment program. At ANL work is in progress to develop technology for converting HLW to a suitable waste form. ANL is also developing criteria for converting cladding hulls from reprocessing to waste forms appropriate to geologic disposal.

Tritium is especially difficult to contain. BNL is conducting a research and development program to remove tritium from effluents and convert it to a solid final waste form (DOE/NE-0008, 1980).

Westinghouse Electric Corporation at the Hanford Engineering and Development Laboratory (HEDL) is working on an acid digestion treatment process for TRU-contaminated solid waste. HEDL is also developing more suitable methods to solidify non-HLW (DOE/NE-0008, 1980).
At the Idaho National Engineering Laboratory (INEL), EG\&G and Exxon Nuclear Itaho Company (ENICO) are engaged in developing methods to convert Idaho HLW to an acceptable final waste form. EG\&G is operating a slagging pyrolysis incinerator to process TRU to a chemically inert, physically stable basalt-like residue suitable for disposal in a repository (McKinley et al., 1980). ENICO is involsed in the vitrification of highlevel alumina defense waste (Brotzman, 1980).

ORNL is studying volume reduction. waste packag ing. and disposal of HLW. ORNL intermediate-level waste, TRU waste. and tritium-contaminated waste. ORNL is also deternining decay characteristics of lightwater and liquid metal fast breeder reactor fuels. HLW. and ciadding hulls (Croff and Alexander. 1980). In addition, they are investigating the compatibility of 6 different waste forms and 15 potential canisters (Blanco and Lot1s, 1980).

PNL. operated by the Battelle Memorial Institute. is studying methods to vitrify HLW. PNL is also responsible for screening candidate engineered harrier materials through the Materials Characterization Center (DOE/EIS-0046F, 1980). Materials that seem promising are graphite. alumina. ethylene propylene rubbers. polyphenylene sulfides. filled epoxies, and ethylene-tetra Muorethylene copolymers (DOE/NE-0007. 1980).

Rockwell International Corporation is involved in developing technology to convert HLW to final waste forms at RHO and is investigating fluidized bed incineration of TRU waste at Rocky' Flats.

SRL is conducting studies to convert Savannah River HLW to a suitable waste form. In addition. SRL has built a full-size sludge calciner. melter, and off-gas collection system for nonradioactive testing and demonstration of waste solidification systems. Still under development at $S R L$ is an ion-exchange system for improved removal of cesium and strontium (DOE/NE-0008. 1980: Wicks, (981).

\section{B. Package Program}

The waste package is a multicomponent system intended to isolate the waste from the geologic environment of the repository (Fig. 3). The package design is based on the multiple barrier concept consisting of the waste form, stabilizers (fillers), canister, overpack, sleeve, and backfill (Basham and Cudnick, 1981).

The most likely waste form will be spent fuel assemblies, as reprocessing of spent commerical fuel has 


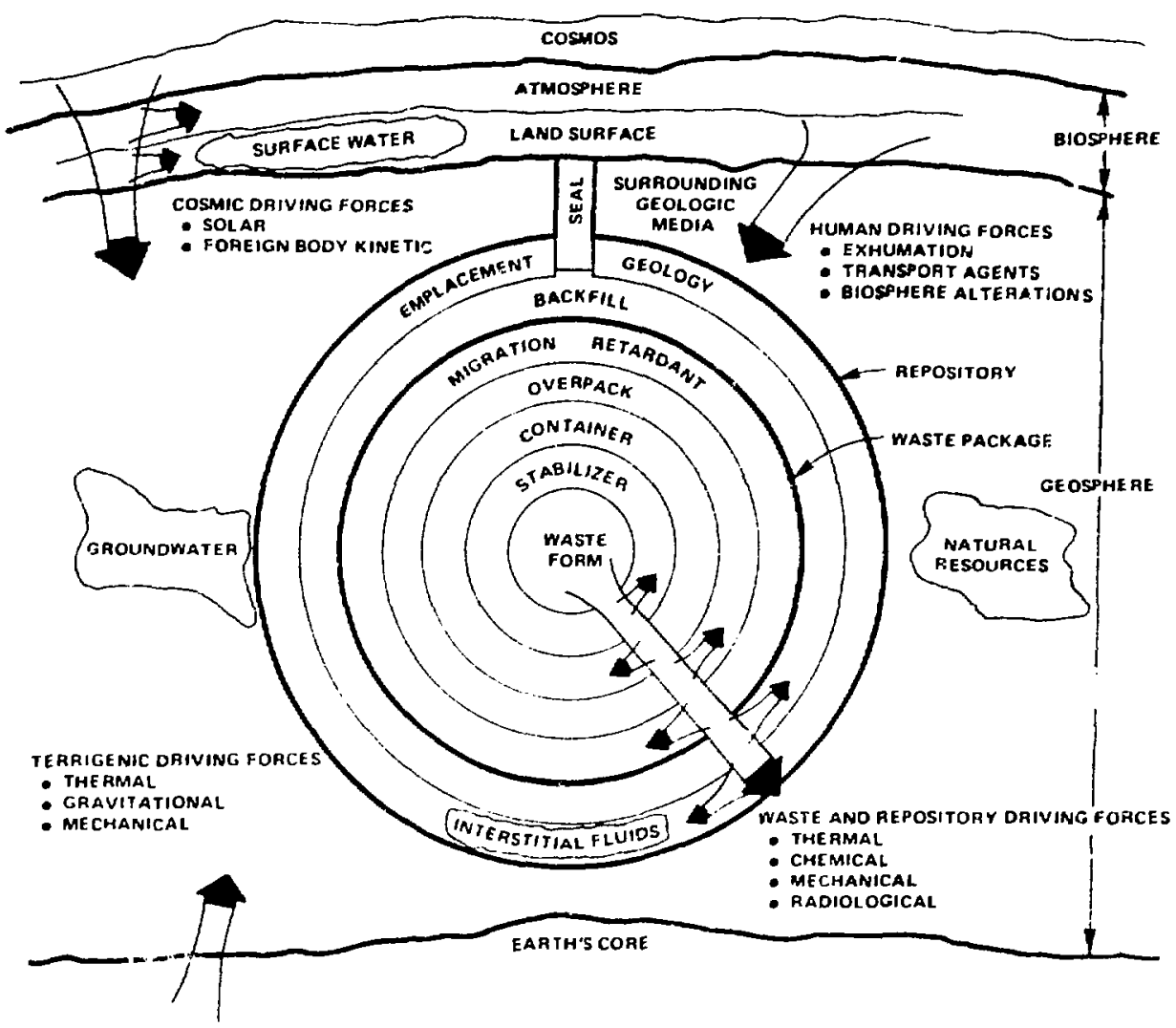

Fig. 3. General waste package design."

${ }^{\mathrm{a}}$ From DOE/NE-0008 (1980).

not been authorized. Laboratory experiments are underway to study radionuclide release from spent fuel in leachants of varıous ground water compositions. New studies include the effects of the degrec of oxidation and chemical distribution on nuclide release. These studies are being performed under both oxidizing and nonoxidizing conditions in ground water. Current accelerated release rate studies are investigating the behavior of simulated spent fuel in deionized water and simulated salt brine at 100 to $300^{\circ} \mathrm{C}$ and unider pressure up to 30 $\mathrm{MPa}$, followed by examination of the alteration and degradation of the original solids and the chemical species taken into solution.

The Spent Fuel Handling and Packaging Program is being conducted by the Westinghouse Advanced Energy Systems Division at the Engine Maintenance Assembly/Disassembly (EMAD) facility at (NTS). The objective of this program is to develup and test the capability to encapsulate spent fuel (Duncan. et al. 1980).

Stabilizers are used as fillers between the spent fue! and the canister. The most likely candidates at the present time are inert gases and stable solids, such as glass or various alloys. The basic physical and chemical properies are known, so major new developments are probably not required. Testing of the solid stabilizer materials can also be applied to possible uses as canister, overpack, and sleeve materials (DOE/NE-0007, 1980).

Candidate materials for the canister, overpack, and sleeve include metals, ceramics, carbon, glass, and cement. Studies of these materials have dealt with corrosion rates, susceptibility to pitting and crevice corrosion, stress corrosion cracking, the effects of oxygen concentration, solution volume to solid surface area ratios, and the possible effects of radiolysis products (DOE/NE-0007, 1980). 
Emplacement hole backfill materials are currently being studied in the United States and in Sweden by Kärnbränslesäkerhet (KBS). Investigations include selective nuclide sorption capacities, ability to retard ground water movement, thermal conductivity, mechanical support strength, swelling, plastic flow, and emplacement forms and methods. The proper backfill material used in a repository will depend very strongly on the geologic environment and is thus fairly site specific. Detailed studies can take place only after a site has been selected. ORNL has evaluated several backrill materials for a repc sitory in bedded and dome salt (Jenks, 1979).

An important part of the Waste Packaging Program is to assess the possible interactions between the various package components under repository conditions. A Swedish proposal of combining a thick copper canister with a bentonite clay backfill has been approved hy a subcommittee of the National Academy of Sciences. Studies of package systems in salt are addressing (1) characterization of candidate backfill and container materials interactions; (2) dry rock salt and various metals; (3) radiation, brine, salt, and metals; and (4) simulated spent fuel, basalt or shale and ground water under hydrothermal conditions. PNL and SNL are initiating hot cell laboratory tests of package systems and bedded salt under hydrothermal conditions using radioactive waste.

\section{Alternate Waste Forms}

The most likely waste form (at least in the near term) is unreprocessed spent fuel assemblies. There are, however, many alternatc waste forms uncier consideration, including glasses of various composition, crystailine waste forms, and composite waste forms, all in different stages of development. The main goal of these R\&D efforts is solidification, as reprocessing results in several liquid waste streams. The major factors influencing the design of a preferred waste form are the age and chemical composition of the waste, properties of the repository host rock and the waste package, and the time period over which the integrity of the waste and container must be maintained.

\section{Glass Waste Forms}

Glass production is a well-developed technology that has been used in industry for many years and is thus more advanced than the other waste form technologies. Glass is naturally unstable and will spontaneously de- vitrify with ime. Many studies have shown that leach rates increase with increasing temperature (DOE/NE-0007, 1980).

Two types of glass are under consideration: low-temperature and high-temperature glasses. Lowtemperature glasses are these that melt below $1200^{\circ} \mathrm{C}$. Th:se are generally of borosilicate composition. though some phosphate glasses are being investigated at PNL and SRL (Cornman. 1980: DOE/EIS-0046F. 1980). The glass casting is formed containing one third or more w $\%$ HLW oxide. then encapsulated in a metal canister for added protection. The only significant effect of devitrification seems to be a slight increase in leach rates.

High-temperature glasses (those that are formed above $1200^{\circ} \mathrm{C}$ ) generally contain more silica or alumina and are more stable at higher temperatures. A nepheline waste glass produced in Canada from 1958 to 1960 seems quite good (DOE/NE-0007, 1980).

SRL has been charged with the tasi of developing by October 1983 two to three alternatives to borosilicate glass (Cornman. 1980). The Idaho Chemical Processing Plant (ICPP) is studying methods to vitrify zirconia calcine and ANL is engaged in testing models for britle fracture of Pyrex (Cornman, 1980: Steindler. 1980a. 1980b). Westinghousc Research and De:'elopment Center is currently developing a new aikoxide process for waste vitrification. Recent studies in Australia (Hirsch. -980) suggest thai some glasses containing alkali metais or alkaline earths may degrade when irradiated and csposed to even low-moisture conditions. There are several proprietary programs directed toward the lowtemperature formation of high-silica glass. for which information is not available.

\section{Crystalline Waste Forms}

In addition to glass. which is amorphous, several alternate waste forms being studied are crystalline. These include cement and concrete. calcine, arid synthetic mineral:s.

a. Cement and Concrete. Cement is used routinely to encapsulate low-level and intermediate-1evel wastes. Portland cement is used most commonly, but may be mixed with fly ash and clay or some other high-alumina cement (DOE/EIS-0046F, 1980; Moore et al., 1981). Various cements and cement combinations are being investigated at PNL and SRL.

The use of concrete as a final waste form is being studied at BNL, ORNL, Pennsylvania State University, 
and SRL. Concrete is currently being used in in situ applications in ORNL hydrofracturing programs for the disposal of intermediate-level waste. One high-integrity concrete being developed by ORNL and Penn State is the FLETAP (formed under elevated temperature and pressure) hot pressed concrete. FUETAP is formed at about $250^{\circ} \mathrm{C}$ and $4 \mathrm{MPa}$ (Moore, 1979; Moore et al., 1981). Recently, a nomograph has been developed at ORNL to aid in predicting leach rates (Blanco and Lotts, 1980).

b. Calcine. The calcination process produces a dry amorphous powder of waste oxides. Because of its high surface area, leach rates are high. The thermal conductivity is low and the powder may form some crystalline phases, releasing nitrates and water, which may decompose under irradiation and pressurize the container. Calcine has been produced from defense HLW by the fluidized bed process at ICPP since 1963. Because of the adverse properties of the powder, stabilization experiments are underway to pelletize existing calcines for either direct disposal or as an ingredient to some matrix waste form (Cornman, 1980; DOE/EIS-0046F, 1980). Calcine development is also being conducted at PNL.

c. Synthetic Minerals. This option is based on the premise that many naturally occurring mineral phases are quite stable over long time periods. Synthetic minerals for HLW are solid solutions of waste incorporated into artificially produced mineral species.

Supercalcine is under development at PNL, Penn State, and Rockwell International. One technique under investigation is to add chemical modifiers to the HLW liquid or solid phases before calcining. After calcination the product is hot pressed or sintered to form a ceramic. Some of these tailored ceramics include clays. Studies at PNL suggest that hot pressing of supercalcine in graphite may be superior to cold pressing and sintering (Cornman, 1980). Another technique being tested at PNL and Penn State may be especially good for actinides. The actinides are partitioned from the waste then incorporated into fluorite and monozite structures.

SYNROC (synthetic rock) is a solid solution of waste and the minerals hollandite, perovskite, and zirconolite. Usually, the calcined HLW is mixed with the SYNROC constituents, hot pressed at 1200 to $1300^{\circ} \mathrm{C}$, and seiled in nickel containers. Waste loading must be limited to $10 \%$ or less to avoid perturbing the known stability of the host minerals. ANL is investigating fabrication of mixture of SYNROC-B and synthetic waste having a waste loading of $10 \%$ (Steindler, 1980a, 1980b). ORNL is studying the fabrication of SYNR OC-B spheres using an internal gelation process rather than hot pressing (Cornman, 1980). A modified SYNROC-B is under investigation at North Carolina State University, and recent work at LLNL suggests that hot pressing of SYNROC-C is potentially feasible (Cornman, 1980).

For waste isolation purposes, titanates, niobates, and zirconates are artificial minerals of waste cations. A small program is underway at SNL. to determine the practicality of hot pressing or sintering these minerals (primarily calcium titanate) to a final waste form (Conman, 1980).

\section{Composite Waste Forms}

Other alternatives to spent fuel are the conposite waste forms. Particles or spheres of radioactive materials are surrounded by one or more different nonradioactive materials. The encapsulating materials may be metals or ceramics to increase the thermal conductivity and/or fracture resistance of the final product. Leach rates arc generally similar to those of glass.

Glass ceramics are normally formed as a glass, then devitrified or crystallized under controlled conditions. This process has become commercially important in the last 20 years. Most of the $R \& D$ work on glass ceramics is being conducted in Germany by the Hahn-Meitner Institute and at Karlsruhe. PNL, in cooperation with this larger program, is attempting to sinter or hot press waste/glass frit to reduced radionuclide volatilization and chemical corrosion (DOE/NE-0007, 1980). Leach testing of various ceramic waste forms is underway at ORNL (Blanco and Lotts, 1980). Rockwell Energy System Group is currently investigating high-alumina tailored ceramics for immobilization of Savannah kiver Plant wastes (Cornman, 1980).

Matrix waste forms are dispersions of wastes in a matrix of glass or metal. The Catholic University of America is developing a process called molecular stuffing, in which porous glass is soaked in $\mathrm{HLW}$, then cleaned and sintered. The process is followed by encapsulating in high-silica glass. The final product has the durability of high-temperature glass formed at lower process temperatures (Cornman, 1980).

The metal matrix waste form consists of calcine, glassy beads, or ceramic pellets in a sintered metal matrix. A joint German-Belgian study (the PAMELA 
process) is scheduled to begin in the early $1980 \mathrm{~s}$ (DOE/EIS-0046F, 1980). ANL is engaged in physical testing (impact) of lead glass to determine the feasibility of the metal matrix concept (Steindler, 1980a, 1980b). PNL is demonstrating the encapsulation of glass marbles embedded in a lead matrix (Cornman. 1980).

Cermet is a uniform dispersion of fission product oxides in a metal matrix. The process usually involves in siiu precipitation. Cermet development is being conducted at ORNL. One advantage of cermet is that high waste loading is possible (DOE/EIS-0046F. 1980). Leach testing of cermet waste forms is underway at ORNL (Blanco and Lotts. 1980; Moore et al.. 1981).

The development of coated particles is based primarily on technology for the manufacture of HTGR fuel. The process involves coating pellets of calcine. supercalcine. or some sintered product with a more leach resistant material. followed by incorporating them into a metal matrix to increase thermal conductivity and strength. Coating materials under investigation include graphite and silicon carbide (DOE/NE-0007, 1980).

\section{REPOSITORY PERFORMANCE ASSESS- MENT}

This section discusses the methods used to analyze the waste disposal system to ensure that it will conform to the requirements for isolation. These studies include the development of descriptive and predictive models for long-term performance of the repository and waste package systems, and experimental programs to test and verify these models.

\section{A. Assessment of Long-Term Performance}

The safe disposal of nuclear waste depends heavily on reliable predictions of tiie? term performance of the repository system. Performance assessment consists of analyzing the potential phenomena that may result in radionuclide release and transport to man. The waste disposal system has four components: (1) the waste package. (2) the repository, (3) the geosphere, and (4) the biosphere. The analyses use mathematical models to describe the state of the system at the time of site closure, then to describe the effects of potential phenomena that could cause a breach of containment. The models then predict the modes of release and transport and the ultimate effects on people. Indi:idual models represent specific phenomena, whereas more complex coupled models describe several competing plienomena. Input parameters are obtained from experimental data and theoretical calculations. The models must be subjected to a rigorous lesting and verification procedure before they can be used with confidence. Long-term performance analyses are applied to (1) site selection and evaluation, (2) design development and evaluation of repositories and engineered barriers. and (3) repository qualification and licensing.

\section{Far. Field Performance}

Far-field phenomena are those that occur in the host rock of the repository and beyond. They are the effects of heat. natural phenomena. and human activities. Most models designed to assess far-field performance are sufficiently well developed to be used at generic and specific sites (DOE/NE-0007. 1980). Many natural phenomena have been studied in detail by the USGS, Los Alamos, and SNL. including ciimatic changes, glaciation, deformation of the host rock. meteorite impact. and earthquakes.

A basic part of the analyses is the scenario describing an assumed sequence of events that cause release. Scenarios are site specific because phenomena that may occur at one site may nol be possible at another- Worstcase analyses describe highly improbable events that serve to fix boundary conditions for the possible effects of release mechanisms. Scenario development is directed by the Waste Isolation Performance Assessment Program (WIPAP) at PNL (Bradley. 1979: Benson, 1979: Stottlemyre, et al. 1980; Raymond et al.. 1980).

Consequence analyses predict the consequences of the assumed scenarios by modeling nuclide transport and dose delivery. Many consequence analyses have been performed for fluid flow through porous media and. more recently, for radionuclide transport (DOE/NE0007. 1980). Models for fracture flow are not as universally applicable as those for porous media. but a considerable effort by the USGS and LBL is being directed toward their development. The USGS is also attempting to obtain solutions to complex transport equations and LBL is developing some of the analytical transport models. Improved models describing radionuclide sorption are being investigated by the Waste-Rock Interactions Technology (WRIT) program at PNL, assisted by Bechtel International. Brine migration models are being ceveloped at the University of California, Berkeley. The probabilities of the possible scenarios at a candidate site will be used to determine 
which cases are credible and limiting, followed by consequence analyses of these for licensing.

\section{Near-Field Performance}

Near-field phenomena, which occur very close to the waste, are the effects of heat, radiation, and repository construction on the waste package. To assess these phenomena the modelers must consider mechanical stresses, heat flow. chemical interactions, and radiation effects. In general. near-field performance assessment is not as wel] developed as for the far-field. Specific physical interactions that still need work are the thermomechanical effects of creep on salt and of fractures in granite (DOE/NE-0007, 1980).

There are three principal types of near-field models. These are (1) heat transfer, (2) thermomechanical, and (3) waste package-rock interactions.

Heat transfer models describe heat flow from the waste through the repository system. More than 40 models have been identified as useful for waste disposal (DOE/NE-0007. 1980). These models generally deal with specific mechanisnis or rock types, but many have overlapping capabilities so that results from several can be cross-checked. Thermal models have been used to predict temperatures in field tests of spent fuel and heaters in salt. granite, and shale. Two models developed at ORNL are designed to predict the effects of ventilation. PNL has produced a code to determine the temperature of spent fuel rods within the waste package. Predictions are being compared to measurements of fuel in surface storage facilities. Experimental results of model validation studies suggest that the precision of thermal niedels can be as high as $\pm 5 \%$ (DOE/NE-0007. 1980).

Thermomechanical and rock mechanic codes describe the thermal and mechanical stress and strain on the repository system. For continuous media. the constitutive relations can be calculated from theoretical considerations with some laboratory verification: for fractured media, extensive laboratory data are needed for model development. RHO, the University of Mirnesota, and Dames \& Moore are developing numerical models of rock stresses in a basalt repository and the University of Minnesota is studying simulated thermomechanical stresses in salt (Crouch, 1979). ORNL is preparing models of salt in brine under controiled thermal and meclianical stress (Shor et al., 1979). RE/SPEC. Inc. is performing thermoelastic analyses of salt at Avery Island (for ONWI) and the WIPP (for SNL), granite at
NTS (for LLNL), and other plutonic rocks in Canada (Callahan and Gnirk. 1979). Science Applications. Inc.. Texas A\&M. and LBL are invectigating the thermomechanical response of salt (Heard. 1979: DOE/FIS-0046F, 1980). The University of Minnesota is developing models to describe the effects of rock dis. placemeri?s and discontinuities. Models describing thermomechanical effects on ground water (USGS) are expected to be fully verified by 1987 (DOE/NE-0007. 1980).

The interactions between the waste package and the host rock involve six types of problems: (1) movement of fluids near the package. (2) corrosion of the canister and sleeve. (3) dissolution of the waste matrix. (4) radio. nuclide sorption on the rock and engineered barrier. (5) absorption of radiation, and (6) changes in chemical phases and rock properties near the canister. Most modeis addressing these problems assume eyuilibrium and rely on available data regarding disiolution. precipitation. and formation of solubie complexes and free ions. Many of the models include temperature as a variable. There is a continuing effort to adapt existing chemical models to waste disposal purposes. Successful coupling of chemical and hydrologic mass transpori models has been achieved for shallow land burial sites at Hanford (DOE/NE-0007. 1980). Battelle Columbus. PNL, and LBL are attempting to obtain data on the basic thermodynamic properties of some actinides, fission preducts, and minerals common to crystalline rocks. Advanced models of very complex phenomena are expected to be completed by 1982 and a DOE USCSS study group reports that coupled and verified models of waste package-host rock interactions will be available $h:$ 1985 (DOE/NE-0007. 1980).

\section{B. Technical Basis for Models}

Experimental data are required in all stages of model development and validation. NWTS experimental prcgrams are designed to assist in model formulation. development of a data base for model application, and verification of their prefictive capabilities. Experiments may also serve as demorstrations of progress.

There are three general classes of experiments: (1) laboratory and bench-scale testing. (2) in situ testing. and (3) observation of natural systents.

Laboratory and bench-scale tests are geared toward small-scale, relatively short-term experiments conducted under strictly controlled conditions. These are followed by in situ tests to study the systems under field conditions. Many variables. however, are difficult or 
impossible to control. Some phenomena are thus more easily characterized by laboratory tests, while others are best studied in the field. Observing natural systems may provide information on long-term phenomena or effects that cannot be adequately studied in a few months or years.

\section{Laboratory Experiments}

a. Waste Package Experiments. Many experiments have been completed or are in progress to characterize the interactions between the waste package and repository host rock. These studies are directed primarily toward package degradation under hydrothermal and irradiation conditions (DOE/NE-0007, 1980; DOE/EIS0046F, 1980; Kosiewicz and Zerwekh, 1980).

Experiments to study brine migration in salt have been conducted by SNL. and the behavior of fluids in granite and basalt is under investigation by Los Alamos and ORNL, respectively. Los Alamos has concluded a program to study the effects of microbial activity on TRU waste under conditions expected at the WIPP (Barnhart et al.. 1980) but no other studies of this kind have been identified. For the past several years, RHO, PNL. and others have been investigating leaching of waste and package components in various solutions (Katayama et al., 1980; Komarneni et al., 1980). These experiments include (1) measurement of releases from spent fuel in various leachants at temperatures up to $300^{\circ} \mathrm{C}$ : (2) corrosion tests $6 i$ potential canister-sleeve and overpack materials: (3) physical properties and radionuclide sorption characteristics of backfill materials: and (4) investigation of radionuclide speciation for various conditions caused by fluids in the host rock. radiation interactions, and the presence of other waste package components. More complex experiments are now being designed to investigate the interactions among the waste form. canister, and backfill materials (DOE/NE-0007. 1980).

\section{b. Repository Analyses and Design Studies. An ef-} fective assessment of repository performance during the operational and postclosure phases requires models to describe rock stress, temperature, deformation, and the abjlity of the host rock to transmit water. Model inputs are often obtained from laboratory tests. LBL, SNL, Science Applications, Inc.. RE/SPEC, Inc., South Dakota School of Mines, and Texas A\&M are engaged in thermomechanical and creep testing of salt. Continuing bench-scale experiments on salt and granite are being conducted by the USGS and SNL. LLNL is performing laboratory studies on several rock types over a range of lithostatic pressures, deviatoric strcsses, and temperatures expected near a repository (Heard, 1979; DOE/NE-0008, 1980).

Laboratory data are needed to support models for radionuclide transport through rock and the biosphere. Current studies include experiments by Los Alamos, Arizona State University, the University of California, Santa Barbara, PNL, and RHO to determine the factors affecting radionuclide sorption (Serne and Relyea. 1979; Salter and Ames, 1980; DOE/NE-0007, 1980). Efforts to develop models describing radionuclide transport through the biosphere and Ĺose delivery are directed toward adapting existing models and no laboratory work is currently being done.

\section{In Situ Testing}

In situ testing is a necessary part of the Nationa: Waste Terminal Storage program. The geologic environment is a complex system in which many factors are interrelated in an extremely complex manner. Some of the relationships are not well understood at the present time. Generic analyses involving computer codes, design assumptions, and laboratory experiments suggest that disposal of HLW in geologic formations is feasible but these results must be validated under actual field conditions. Factors that must be evaluated in the field include:

- radionuclide leaching and migration.

- rates and processes of canister corrosion.

- performance of engineered barriers,

- water flow in and around the repository,

- gas generation.

- validity of mine stability and design criteria, and

- performance of potential repository seals (Robinson. 1979).

Various in situ testing programs are underway at several locations (Fig. 4). These are briefly discussed below.

a. Project Salt Vault, Kansas. Between 1965 and 1968 ORNL conducted, under the auspices of the Atomic Energy Agency, in situ experiments in an abandoned salt mine near Lyons, Kansas. The tests involved thermal simulation using electric heaters and the emplacement of actual spent fuel. Seven canisters containing 14 spent fuel assemblies from the Engineering Test Reactor at INEL were used in the experiments. The 


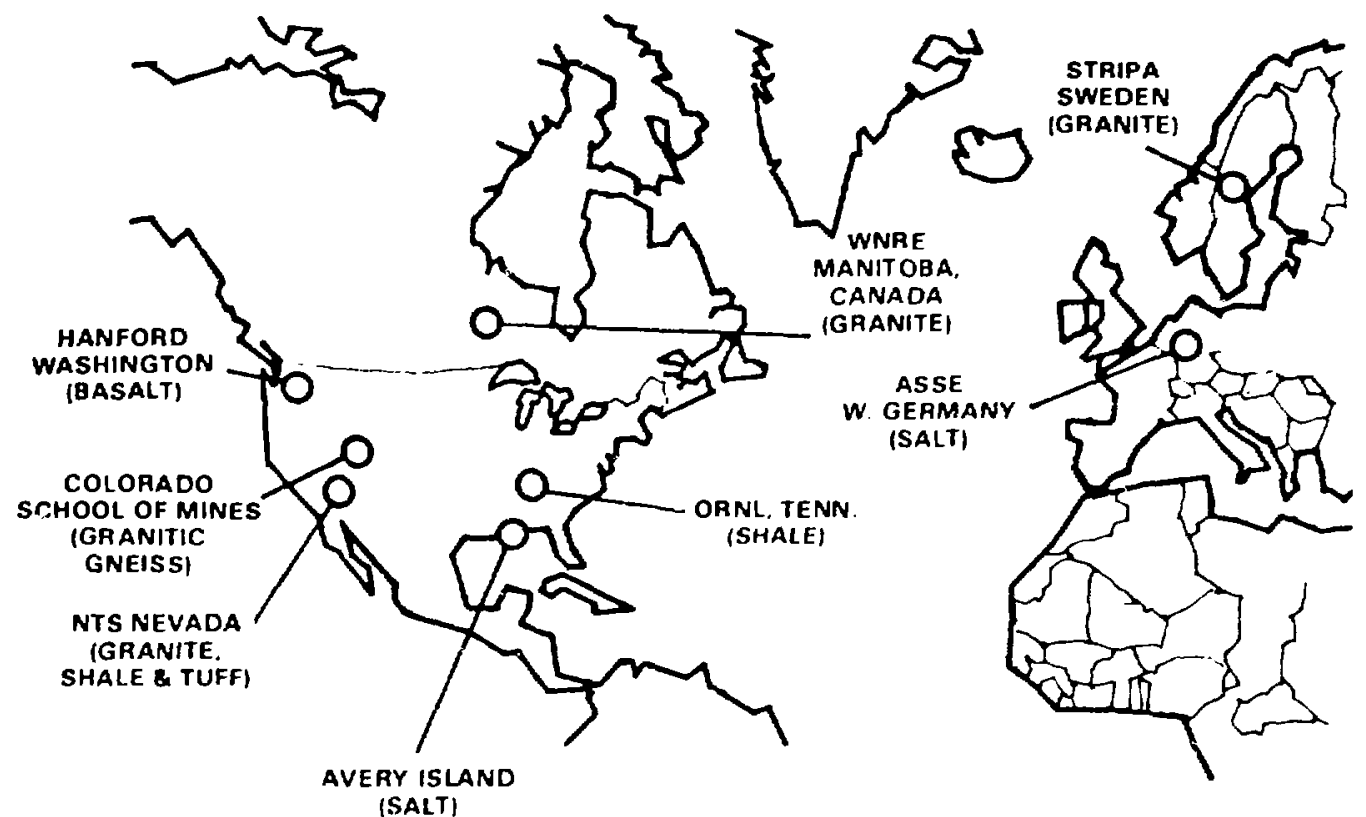

Fig. 4. In situ testing sites |From DOE/NE-0008 (1980)].

program plan called for replacing the waste every 6 mo over the 19-mo test. so that a total of about $4 \times 10^{6}$ $\mathrm{Ci}$ of fission-product activity in 21 canisters were transferred to the facility (McClain and Bradshaw, 1973). At the end of each phase the spent fuel was retrieved and returned to ICPP. The objectives of this program were to demonstrate waste handling techniques. determine the gross effects of radiation on salt, study the radiolytic production of chlorine, and collect data on creep at temperatures of 100 to $200^{\circ} \mathrm{C}$ (DOE/NE-0007. 1980). All the predictions of thermal and radiation effects based upon theoretical modeling and laboratory experiments were confirmed by the in silu demonstration (McClain and Bradshaw, 1973). No radiolytic chlorine was detected and there were no detrimental effects on the salt (DOE/NE-0007, 1980).

b. Asse II, Federal Republic of Germany. Asse II is an experimental disposal facility in the Federal Republic of Germany. This salt mine has been in operation for more than I4 yr, handling low- and intermediate-level wastes. Recently, accortance of the intermediate-level waste has been curtailed pending licensing proceedings. Experiments at Asse II include (1) developing and testing of disposal methods for vitrified HLW, (2) testing the stability of underground openings at ambient temperatures, (3) heater tests to study temperature per turbations and brine migration, and (4) testing emplacement technique and performance of backfill and penetration seal materials. Plans are being made for a joint US-German brine migration test to verify laboratory tests and models.

c. Waste Isolation Pilot Plant. On January 22. 1981 Duane Sewell, Assistant Secretary for Defense Programs, mandated the development of the Waste Isolation Pilot Plant (WIPP) according to Alternative 2 of the WIPP final environmental impact statement (DOE/EIS-0026, 1980). As now scheduled, the WIPP will receive $176000 \mathrm{~m}^{3}$ of contact-handled and $7080 \mathrm{~m}^{3}$ of remote-handled TRU waste from INEL. In addition. 40 canisters of HLW will be installed for experiments on brine migration and radiation effects. All HLW will be retrieved upon completion of the experiments. If the WIPP is developed according to the proposed schedule, the transfer of TRU from INEL should be complete by the early 1990s, at which time TRU transfer from other DOE facilities should begin. The WIPP should be filled by 2003 (Nucleonics Week, 1981). 
SNL is the prime contractor for the WIPP. Various laboratory and bench-scale experiments have been conducted in support of the WIPP since 1976. In situ experiments to investigate borehole seals and evaporite gas permeability were conducted in 1979. Several cooperative experiments with local potash mines have been performed to determine environmental conditions and pillar deformation during mining.

The Site and Preliminary Design Validation (SPDV) program is desicned to provide final site validation anc? to verify design analyses before acyal facility construction begins. This program will require a $2-y r$ period of construction and site validation followed by a $5-y r$ operational period for design validation. T/1e SPDV facility will consist of two deep shafts and a $0.08 \mathrm{~km}^{2}$ underground geologic experimentation facility. No radioactive materials will be used in any of the experiments. These in situ tests will be (1) repository design corformation experiments to study the stability of various excavation zonfigurations; (2) heater tests for thermomechanical response, fluid migration, and performance of waste package components, and (3) experiments to investigate operation and design, waste emplacement techniques, retrievability methods, mine-face scanning, and instrumentation development. Plans include full-size waste canisters and unpackaged waste forms. If any significant new environmental data result from the tests, the final environmental impact statement will be supplemented by a new National Environmental Policy Act (NEPA) review.

d. Avery Island, Louisiana. These in situ tests are being conducted by RE/SPEC, Inc. at the $168-\mathrm{m}$ level of a mine in a salt dome near Iberia, Louisiana. Three heater tests have been in progress since June 1978 to study the thermomechanical response of dome salt (Hansen and Mellegard, 1980). Other current experiments are investigating synthetic brine migration in a temperature field, corrosion characteristics of various metals, and radaî techniques for detecting structural discontinuities and to locate canisters.

Results to date indicate that there is no major deviation in thermomechanical response of the dome salt from that of the bedded salt studied in Project Salt Vault. The in situ thermal conductivity is up to $20 \%$ higher than predicted from laboratory measurements.

New experiments being planned are to (1) measure salt permeability in natural salt and around heaters, (2) obtain a preliminary assessment of backfill consolidation at different temperatures and pressures, (3) study means to accelerate borehole clcsure, (4) investigate fracture healing, and (5) evaluate the peformance of new heater designs (DOE/NE-0007, 1980).

e. Stripa. Sweden. The S. zipa facility is located in a 340-m-deep tunnel excavated in a quarzz monzonite pluton adjacent to an iron ore mine. Kämbränslesäkerhet (KBS. Nuclear Fuel Safety Program) and Lawrence Berkeley Laboratory (LBL) have been engaged in hydrologic and geochemical investigations at the site since 1977. The purposes of these studies are to (1) $\therefore$ rirm existing computer cudes for temperature profii $\cdots:$ i. wet. jointed, hard rock; (2) measure rock mass permeabitity as a function of temperature and pressure: (3) determine the magnitude and principal directions of in situ stress; (4) determine thermally induced stresses anj deformation around heaters and related phenomena resulting from heating; and (5) test macroscopic methods to define the combined buik and fracture permeability. The following discussion is referenced to a recent publication by Witherspoon et al. (1981).

Thermomechanical investigations at Stripa involve both full-scale and scaled heater experiments. The full-scale heater experiments are designed to determine the short-term effects of thermal loading. Two heaters were emplaced beneath the tunnel floor, adjusted to 5 and $3.6 \mathrm{~kW}$ to simulate 3 -yr-old and 5-yr-old HLW, respectively. The results show excellent agreement between predicted and measured values. Fractures and water filling them had a negligible effect on the thermal field.

The scaled heater experiments were used to study the effects of the maximum temperature that would be experienced during the time period of 10 to $100 \mathrm{yr}$. The time factor was compressed in the ratio of 1:10 by using the laws of heat conduction. Although the measured thermal expansion of the rock was significant $\left(\sim 10^{-3}\right)$, there was. again. good agreement between predicted and measured values. The dominant mode of heat transfer was determined to be conduction.

A series of extensiometers was emplaced adjacent to the full-scale heater test to measure rock displacements and stresses resulting from heating.

During the first few weeks, measured displacements were much less than those predicted, followed by a uniform increase at about 0.4 of the predicted values. The cause of this discrepancy may be an insufficient number of laboratory measurements to adequately characterize the physical properties of the rock. Similarly, the 
observed stress values were $\leq 0.5$ of those predicted. Clearly, more laboratory work is needed.

An acoustic tomographic technique developed at LBL, using only two sets of downhole acoustic sources and receivers, was used to measure the orientation, spacing, and length of joints and fractures. Thus, fracture mapping can be accomplished without extensive drilling.

Some work has been done to study ground water movement through fractures. So far, research has consisted only of large-scale permeability testing. Geochemistry and isotope hydrology have been used to determine the ages and relative sources of decp and shallow ground water at the Stripa site.

f. Studsvik, Sweden. Studsvik is an experimental facility in a migmatitic-gneissic granite $90 \mathrm{~km}$ south of Stockholm. KBS conducted tests here to investigate nuclide migration in fractured crystalline rock. Experiments consisted of injecting small amounts of Se, Tc, Sn, $\mathrm{Cs}, \mathrm{I}, \mathrm{Nd}, \mathrm{Sr}$, and $\mathrm{Br}$ into one borehole and pumping from another to determine effective sorption coefficients. The measured values showed good correlation with those determined in the laboratory. In order to study the effects of artificial fracture fillers, a bentonite slurry was injected into the system and the experiment repeated. Bromine-82 and strontium-85, used as tracers, were not detected in the monitoring holes after $1 \mathrm{yr}$, suggesting that the bentonite was capable of reducing $\mathrm{Sr}$ migration to less than $1 \%$ of the previous rate.

g. Climax Stock, Nevada. The Piledriver Facility is located at the $427-\mathrm{m}$ depth in granodiorite and quartz monzonite of the Climax Stock at NTS. The objectives of the experiments conducted by LLNL are to (1) simulate the environment of waste canisters and measure their effects on plutonic rocks, (2) evaluate the differences between radioactive waste sources and electric simulators, (3) compare the mechanical responses, caused by mining and heat loading, of the rock, (4) compare the predicted and measured amounts of heat removed by ventilation, and (5) compare the thermomechanical responses of highly fractured and less fractured rock.

Preliminary electric heater tests were completed in 1978, yielding valuable information in in situ thermal properties and permeabilities. The tests also provided verification for a thermal and analytical model.

Drilling and mining for the spent fuel test was completed in 1979 and fuel loading began in March
1980. The spent fuel is processed through the Engine Maintenance Assembly/Disassembly (EMAD) facility at NTS. A total of 11 spent fuel elements and 6 electric heaters are being used in the 3- to 5-yr experiment (Lincoln, 1979).

h. Colorado School of Mines Experiniental Mine, Colorado. The Colorado School of Mines has excavared a tunnel in its experimental mine near Idaho Springs. Colorado, for use in NWTS investigations. The tunnel is at the $300-\mathrm{m}$ level in granite gneiss. Activities are to (1) assess the effects of blasting on rock masses and to develop smooth-wall blasting techniques, (2) determine constitutive relationships for crystalline rock masses, and (3) evaluate heated flat-jack tests as a method to obtain mechanical properties of jointed rock masses for input into thermomechanical models. Extensiometers were installed to provide data on rock-mass behavior during excavation and fracture permeability tests are being conducted (Hustrulid, 1979).

i. Eieana Argillite Test, Nevada. NTS hosted a series of tests to evaluate argillite as a potential repository medium. Tha tests were conducted to (1) determine the phenomena resulting from heating, and (2) confirm thermal models to predict these effects. The results indicated that, at temperatures near $100^{\circ} \mathrm{C}$. thermomechanical response is dominated by the contraction of clay, which results in the opening of pre-existing joints and increased upward fracture permeability. The resulting mineral dewatering causes a reduction in the thermal conductivity below the value measured before heating (DOE/NE-0007, 1980). When these phenomena were included in the thermal model being tested, accurate temperature predictions were obtained. At a repository depth $(\sim 1000 \mathrm{~m})$ the increased lithostatic pressure may lessen the magnitude of these observed phenomena. but additional testing would be required for confirmation.

\section{j. Conasauga Near-Surface Heater Test,} Tennessee. This experiment was conducted by SNL near Oak Ridge, Tennessee to evaluate the response of the Conasauga Shale to thermal loading (Tyler and Krumhansl, 1979). Two heaters were emplaced in $15-\mathrm{m}$ deep holes. The power output was adjusted to $10 \mathrm{~kW}$ then later reduced to $6 \mathrm{~kW}$. The purposes of the experiments were to (1) measure the in situ thermal conductivity and to observe any changes, (2) determine if the primary mechanism for heat transfer in very wet 
rocks involved both conduction and convection, (3) determine if the mechanical response of the rock : "sulted in a significant change in permeability, (4) determine if mineralogical changes were caused by heating, and (5) measure any variations in ground water chemistry as a result of heating (DOE/NE-0007, 1980).

After 8 mo of heating, the results were not as significant as had been predicted. No fracturing or spalling of the heater hole walls was observed, nor were induced fractures detected at a distance. Transmissivity measurements following the test actually showed a decrease in permeability. Clearly. more model development work is needed.

k. Near-Surface Test Facility, Washington. The Near-Surface Test Facility (NSTF), near Gable Mountain at the Hanford site, is located at $100 \mathrm{~m}$ depth in the Pomona Basalt. This formation is similar to the Untanum Basalt, which is being considered as a potential repository site. The objectives of the NSTF programs are to (1) demonstrate the placement, storage, and retrievability of waste canisters; (2) establish a data base for numerical models for the near field and very near field; (3) determine thermomechanical rock-mass properties, such as deformation, thermal expansion. and thermal conductivity, and their variations as a function of temperature and stress; and (4) deternine rock-mass response to thermomechanica! loading and to spent fuel and vitrified waste forms (Dietz, 1980).

Construction at the NSTF was completed in 1979 and rock mechanics/heater tests, still in progress, began in July 1980 (Blanchard, 1980; Kim, 1980).

Jointed block tests, beginning in early 1981, are designed to determine deformability, thermal expansion, and thermal conductivity as a function of temperature, stress, rock-mass quality, and joint direction. These tests will be performed on blocks $2 \mathrm{~m}$ square (Kasper, 1980). A proposed extension of these tests, now under review, is to expand the scale to room size to evaluate the extended thermomechanical response of basalt under expected repository conditions. The tests should (1) demonstrate the feasibility of the test concept, (2) stress large volumes of rock to provide data on the effects of local variations in rock-mass quality, and (3) provide data for the validation of predictive analyses on a room scale under controlled conditions (Kasper, 1980).

Waste testing at NSTF will use spent fuel and a canister of vitrified HLW to evaluate packaging and handling techniques and to determine thermomechanical response of basalt to actual waste forms (Schroeder,
1980). The spent fuel will be characterized, packaged. and shipped through the EMAD facility at NTS. Waste loading is expected to begin in 1982.

An Exploratory Shaft Test Facility has been proposed by Rockwell Hanford Operations (RHO) to provide detailed characterization of a reference repository in basalt at repository depth. The location chosen for the facility is in the Cold Creek Syncline area, near a potential candidate site on the Hanford Reservation. Plans call for the facility to be licensable so as to be incorporated into the final repository, should this site be selected. Characterization includes (1) definition of the geometry of the repository horizon. (2) assessment of subsurface hydroiogic characteristics. and (3) assessment of the stability of an underground opening in basalt at the expected repository depth (Brown. 1980). The schedule provides for pilot holes to be dirilled in 1981 and the completion of a conceptual design by September 1981. Drilling of the shaft could begin as early as FY83 (Marron, 1980).

\section{Observation of Natural Systems}

Analytical models are designed to simulate natural conditions over very long time periods. Laboratory and in situ testing programs are necessarily far too brief to verify these models for the very long term. To help alleviate this situation several programs are underway to study naturally occurring systems that may be considered analogous to a geologic repository.

a. Oklo Natural Fission Reactor, Gabon, West Africa. The Natural Reactor Fission Program is conducting field studies of fission product migration near the Oklo uranium mine in Gabon. West Africa. More than 10 tons of "waste" were produced 2 billion years ago when the original uranium deposit reached criticality. The reaction continued for several hundred thousand years. Most of the fission products nave remained at or near the original site. Studies show that the long-term release rates of most of the reactor products are controlled by solid state diffusion from the uraninite grains. Dissolution of the uraninite has not occurred because the ground water at the site is reducing rather than oxidizing (DOE/NE-0007, 1980). Los Alamos National Laboratory is investigating the release rates of those wastes to validate models of reactor product transport in geologic media over very long time periods (Gancarz et al., 1979). Current studies are using element and isotopic analyses to define transport pathways for specific radionuclides. 
b. Morro de Ferro Thorium Deposit, Brazil. Radionuclide transport models are being tested against measurements of transport and dispersion at the Morro de Ferro thorium deposit in Minas Gerais, Brazil. The deposit is water saturated and measurements of the dissolution and migration of thorjum, uranium, and other rare earths will be used to calibrate models for plutonium transport.

c. Uranium Leaching Experiments, Wyoming. The USGS and US Bureau of Mines are engaged in a cooperative study of a uranium leaching experiment near Casper. Wyoming. Leaching and transport data will be correlated with models to assess the validity of source term assumptions and redionuclide retardation in ground water.

\section{Penetration Sealing}

An essential part of the NWTS program is to ensure that all penetrations into a geologic repository are adequately sealed. Boreholes, access shafts, and tunnels provide pathways for the migration of radionuclides to the biosphere and for potential water inflow into the repository. It is unlikely that any major technological advances will be required to seal penetrations. A considerable amount of related experience has been gained from methods designed to seal oil and gas wells, mines, brine and hazardous chemical waste disposal areas, and NTS underground weapons testing sites. The problem here is to adapt existing technologies. D'Appolonia Consulting Engineers has developed for ONWI a qualitative approach to penetration sealing (D'Appolonia, 1980). They submit that the migration rate through a seal zone should be less by a specific safety factor than the rate determined acceptable by a consequence analysis. The safety factor must be established on a siteby-site and seal-by-seal basis. Thus, the adequacy of penetration seals is a site-specific consideration. Any given seal will probably consist of several components and materials, as no single geometry and material may be sufficient. The total seal system must perform in a satisfactory manner.

Significant factors to be considered in seal design are (1) the geologic environment, (2) characteristics of the penetration, and (3) waste loading and environmental conditions. Important penetration characteristics are listed in Table II.

Also to be considered are the purposes of a seal. An adequately designed penetration seal must (I) retard the
TABLE II

\section{REPOSITORY PENETRATION CHARACTERISTICS ${ }^{2}$}

\author{
Cross $\cdot$ section \\ Depth \\ Age \\ Direction \\ Type of material penetrated \\ Water flow and control devices \\ Physical and chemical properties of the rock \\ Condition of sidewalls and any existing or planned \\ linings or casings \\ Temperalure grs dienı \\ Extent of the disturbed zone

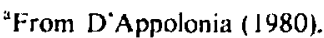

movement of fluids through or toward the repository, (2) retard the migration of radionuclides in any small amount of fluid, and (3) isolate water-bearing strata. Therefore, seal materials must have low permeability, high sorption crnacity, structural strength. longevity, and deformation properties compatible with the surrounding rock.

There are several areas of penetration that must be sealed. These are near the ground surface, at aquifers and other producing strata, within formations whose properties differ with other members of the stratigraphic sequence, at contact with the host formation. and in the immediate vicinity of the repository.

Several programs are currently underway to evaluate sealing materials and designs, including laboratory and field studies of plug materials and configurations, evaluations of long-term stability of materials, and systems and consequence analyses. Most laboratory studies are addressing cementitious materials (Burns, 1979). Geochemical and thermodynamic studies of cements are being conducted by ORNL and Penn State (Roy, 1979; Moore, !979; Moore et al., 1981).

Woodward-Clyde Consultants are performing laboratory tests on 10 candidate plug materials for the BWIP (O'Rourke, 1980). These materials are basalt, bentonite and ringold clay, zeolites, sand, Type II and Type V calcio-aluminate, and Type $K$ portland cement. The preliminary geochemicsl tests, with temperatures and pressures up to $25^{\circ} \mathrm{C}$ and $34.5 \mathrm{MPa}$, were completed in 1980. The materials examined seem to be compatible with each other and with the expected repository environment. Preconceptual design studies are now underway. 
A shallow borehole plugging test is being conducted by RHO in 46-m-deep holes near the Near-Surface Test Facility at the Hanford site (Hodges, 1980). The experiments, expected to begin by 1982 , will provide information on stress-strain and fluid flow characteristics of plugged holes, and on emplacement techniques. Materials being studied are Portland cement grouts and bentonite slurries containing crushed basalt and compressed bentonite pellets.

For the WIPP program, SNL is performing laboratory tests and consequence analyses to evaluate cementious plug materials. Field studies were begun in 1979. Evaluation of a potash exploration hole plug, emplaced in 1961 by SNL, the Army Corps of Engineers' Waterways Experimental Station, and Penn State, suggested that additional testing was needed. This need resulted in the Potash Core Test in which core sections from a 3-yrold plug emplaced during the initial WIPP site evaluation will be examined. The Bell Canyon Test, to evaluate a cement plug in a region with a fluid pressure of $\sim 13.8$ $\mathrm{MPa}$, was successfully completed in 1980 (Likar, 1981). The Surface Wellbore Test Bank has been established for the emplacement and subsequent removal at nominal intervals of 2-, 5-, 10-, 15-, and 30-yr increments of in siru cured plugs for long-term analysis (Christensen, 1979; Gulick et al., 1980).

The University of Arizona is conducting, for NRC, confirmatory research of borehole seals. They are currently studying seals in granite.*

It is expected that quantification of seal designs, including the range of acceptable materials and geometries, and prototype seal designs will be available by late 1982; specific designs appropriate to a repository site should be chosen $2 \mathrm{yr}$ after site selection (DOE/NE-0007, 1980).

\section{SUMMARY AND CONCLUSIONS}

The Nation's endeavor to identify and operate nuclear waste repositories in deep geologic formations represents one of the most technically complex problems ever encountered. Many of the program components are interrelated so that progress in one area depends on adequate advances in another. Site qualification and licensing depend on fully verified mathematical models to predict long-term repository performance. The models rely on laboratory experiments and field tests to provide

-This information provided by J.J.K. Daeman, Geosciences Dept., University of Arizona, February 13, 1981. input parameters and validation. Much of the experimental work must be specific to a particular rock type or site and therefore depends on data obtained by site exploration activities. It should be clear that all phases of the program must be carefully coordinated.

In the area of site selection. geohydrologic screening and exploration are continuing. Regional studies in salt basins are generally well advanced. Some area studies are underway or just beginning. Regional studies for nonevaporite media are still in progress, except at the Hanford site and NTS. A considerable amount of field work and some exploration technique development are required before enough candidate sites are available for comparison.

Waste treatment technology is generally still in the laboratory phase. A few bench-scale experiments and pilot plant tests are now in progress or planned. Many potential waste forms are being evaluated on laboratory and bench scales and acceptable alternative waste forms will probably not be identified before 1983. Possible waste package-host rock interactions are being investigated in the laboratory. A few field tests have recently begun and more are planned. Detailed studies. however, will take place only after candidate sites are selected.

Long-term repository performance assessments are highly dependent on descriptive and predictive models. Many models are in various stages of development. Some. describing far-field phenomena, are fairly well advanced. but those for the near field need much more work before they can be validated. Advanced models describing complex phenomena should be completed by 1982. but those for waste package-host rock interactions are aot expected to be available until 1985. It is anticipated that models describing thermomechanical effects on ground water will be verified by 1987 .

The primary objective of in silu testing programs is to provide experimental data for model development and validation. In situ tests usually require up to several years for completion and many tests are just beginning or are in the planning stage. After a repository site is finally selected, a site validation program, similar to that planned for the WIPP, will be required before licensing.

In the area of penetration sealing. much experience has been gained by the mining and petroleum industries. No new technological advances seem to be needed but the existing technology must be adapted to repository systems. Many different seal materials and geometries are under consideration. Laboratory and field testing of some seal designs is underway at some sites and more is 
planned. The actual seal system to be used, however, cannot be selected and tested until a site is chosen.

The technical program for repository development seems to be well coordinated and well directed, though much more research and development are still required in many areas. Many potential technologies are now under investigation, but specific technologies cannot be identified until a repository site is selected. It is still too early in the program to assess the adequacy of environmental control technologies for deep geologic disposal.

\section{REFERENCES}

B. J. Barnhart, E. W. Campbell, E. Martinez, D.E. Caldwell, and R. Hallett, "Potential Microbial Impact on Transuranic Wastes Under Conditions Expected in the Waste Isolation Pilot Plant (WIPP)-Annual Report, October 1, 1978-September 30, 1979," Los Alamos Scientific Laboratory report LA-8297 (July 1980).

S. J. Basham and R. A. Cudnick, "Waste Package Development-1980," in Waste Management '81, Proceedings of American Nuclear Society Topical Meeting, Tucson, Arizona. R. G. Post, Ed., February 23-26, 1981, pp. 339-352.

G. L. Benson, "Release Scenario Analysis Task," in Proceedings of the National Waste Terminal Storage Program Information Meeting, Columbus, Ohio, October 30-November 1, 1979, pp. 59-60.

R. J. Blanchard, "Design. Fabrication, and Installation of Rock Instrumentation for the Near-Surface Test Facility," in Basalt Waste Isolation Project Annual Report-FY 1980, Rockwell Hanford Operations report RHO-BWI-80-100 (November 1980), pp. V-5-V-14.

R. E. Blanco and A. L. Lotts, "High-Level Waste Program Progress Report for April 1, 1980, Through June 30, 1980," Oak Ridge National Laboratory report ORNL/TM-7476 (August 1980).

D. J. Bradley, "Waste-Form Interactions," in Proceedings of the National Waste Terminal Storage Program Information Meeting, Columbus, Ohio, October 30-November 1, 1979, pp. 41-42.

J. R. Brotzman, "Vitrification of High-Level Alumina Nuclear Waste," Exxon Nuclear Idaho Company report ENICO-1040 (June 1980).
D. J. Brown, "Essential Characterization Data from an Exploratory Shaft Test Facility in Basalt," in Basalt Waste Isolation Preject Annual Report-FY 1980, Rockwell Hanford Operations report RHO-BWI-80-100 (November 1980), pp. VI-37-VI-45.

G. i). Brunton, "Evaluation of Argillaceous Rock for Nuclear-Waste Containment," in Proceedings of the National Waste Terninal Storage Program Information Meeting, Columbus, Ohio. October 30-November 1, 1979, p. 92.

F. L. Burns, "Overview of NWTS Repository Sealing Programs," in Proceedings of the National Waste Terminal Storage Program Information Meeting, Columbus. Ohio, October 30-November 1, 1979, p. 135.

G. D. Callahan and P. F. Gnirk, "Thermomechanical Modeling for Repositories in Geologic Media." in Proceedings of the National Waste Terminal Storage Program Information Meeting, Columbus, Ohio, October 30-November 1, 1979, pp. 34-36.

C. Z. C. Christensen, "Field Test Programs of Borehole Plugs in Southeastern New Mexico," in Proceedings of the National Waste Terminal Storage Prugram Information Meeting, Columbus, Ohio. October 30-November 1, 1979, pp. 148-149.

W. R. Cornman, "Composite Quarterly Technical Report-Long-Term High-Level Waste Technology. April-June 1980," E. 1. DuPont de Nemours Company report DP-80-157-2 (October 1980).

A. G. Croff and C. W. Alexander, "Decay Characteristics of Once-Through LWR and LMFBR Spent Fuels, High-Level Wastes, and Fuel Assembly Structural Material Wastes," Oak Ridge National Laboratory report ORNL/TM-7431 (November 1980).

S. L. Crouch, "Thermomechanical Modeling by Boundary-Element Methods," in Proceedings of the National Waste Terminal Storage Program Information Meeting, Columbus, Ohio, October 30-November 1, 1979, pp. 33-34.

B. M. Crowe, "Research and Development Related to the Nevadis Nuc! ar Waste Storage Investigations, October 1-Dece:"n' r 31 , 1979," Los Alamos Scientific Laboratory re: M LA-8309-PR (April 1980). 
B. M. Crowe and K. Wolfsberg, "Research and Development Related to the Nevada Nuclear Waste Storage Investigations, January I-March 31, 1980," Los Alamos Scientific Laboratory report LA-8419-PR (October 1980).

T. A. Curran, "Summary of Fiscal Year 1980 Geosciences Studies," in Basalt Waste Isolation Project Annual Report-FY 1980, Rockwell Hanford Operations report RHO-BWI-80-100 (November 1980), pp. r. $1-11-4$.

D'Appolonia Consulting Engineers, "Repository Sealing Design Approach-1979," Office of Nuclear Waste Isolation report ONWI-55 (March 1980).

R. A. Deju, "Status Report on Studies to Assess the Feasibility of Storing Nuclear Waste in Columbia Plateau Basalts," in Proceedings of the National Waste Terminal Storage Program Information Meeting, Columbus, Ohio. October 30-November 1, 1979, pp. 9-12.

J. M. Deutch, "Report to the President by the Interagency Review Group on Nuclear Waste Management," TID-29442 (March 1979).

DOE/EIS-0026, "Final Environmental Impact Statement-Waste Isolation Pilot Plant," US Department of Energy (October 1980).

DOE/EIS-0046F, "Final Environmental Impact Statement-Management of Commercially Generated Radioactive Waste," US Department of Energy (October 1980).

DOE/NE-0007, "In the Matter of Proposed Rulemaking on the Storage and Disposal of Nuclear Waste-Statement of Position of the United States Department of Energy," US Department of Energy (April 1980).

DOE/NE-0008, "Nuclear Waste Management Program Summary Document-FY 1981," US Department of Energy (March 1980).

H. B. Dietz, "Summary of Fiscal Year 1980 Near-Surface Test Facility Activities," in Basalt Waste Isolation Project Annual Report-FY 1980, Rockwell Hanford Operations report RHO-BWI-80-100 (November 1980), pp. V-1-V-4.
J. E. Duncan, P. A. House, and G. W. Wright, "Spent Fuel Handling System for a Geologic Storage Test at the Nevada Test Site," Lawrence Livermore National Laboratory report UCRL-83728 (May 1980).

C. O. Durham, Jr., "A Review of Gulf Coast Salt-Dome Evaluations," in Proceedings of the National Waste Terminal Storage Program Information Meeting. Columbus, Ohio, October 30-November 1. 1979. pp. 77-78.

R. C. Edwards, "Geophysical Surveys in the Pasco Basin." in Basalt Waste Isolation Project Annual Report-FY 1980, Rockwell Hanford Operations report RHO-BWI-80-100 (November 1980), pp. II-22-II-25.

Federal Register, "Waste Isolation Pilot Plant: Record of Decisions." Vol. 46. No. 18, pp. $9162-9164$ (1981).

A. J. Gancarz, G. A. Cowan, and A. E. Norris, "Oklo Natural Fission Reactor," in Proceedings of the National Waste Terminal Storagc Program Information Meeting. Columbus. Ohio, October 30-November 1, 1979. pp. 26-27.

S. Gonzales and K. S. Johnson, "Preliminary Assessment of Argillaceous Basins in the United States," in Proceedings of the National Waste Terminal Storage Program Information Meeting, Columbus. Ohio, October 30-November 1. 1979, pp. 90-91.

C. W. Gulick. Jr., J. A. Boa, Jr., D. M. Wallace, and A. D. Buck. "Borehole Plugging Materials Development Program, Report 2," Sandia National Laboratories report SAND-79-1514 (February 1980).

F. D. Hansen and K. D. Mellegard. "Quasi-Static Strength and Deformational Characteristics of Domal Salt from Avery Island, Louisiana," Office of Nuclear Waste Isolation report ONWI-1 16 (January 1980).

H. C. Heard, "Elastic. Thermal, and Permeability Behavior of Generic Repository Rocks at $\boldsymbol{n}$ n Situ Conditions," in Proceedings of the National Waste Terminal Storage Program Information Meeting, Columbus, Ohio. October 30-November 1, 1979, pp. 37-40.

E. H. Hirsch, “A New Irradiation Effect and its Implications for the Disposal of High-Level Radioactive Waste," Science 209, 1520-1522 (1980). 
F. N. Hodges, "The Shallow Borehole Plugging Test," in Basalt Waste Isolation Project Annual Report-FY 1980, Rockwell Hanford Operations report RHO-BWI-80-100 (November 1980), pp. VI-50-VI-53.

D. C. Hoffman, R. Stone, and W. W. Dudley, Jr., "Radioactivity in the Underground Environment of the Cambric Nuclear Explosion at the Nevada Test Site," Los Alamos Scientific Laboratory report LA-6877-MS (July 1977).

R. E. Hosman, "Regional Groundwater Hydrology of the Northern Louisiana Salt Dome Basin in Reiation to the Storage of Nuclear Wastes,"in Proceedings of the National Waste Terminal Storage Program Information Meeting, Columbus. Ohio, October 30-November 1, 1979 , p. 85.

W. Hustrulid, "Mining Technology Development in Crystalline Rock," in Proceedings of the National Waste Terminal Storage Program Information Meeting, Columbus, Ohio, October 30-November 1, 1979, pp. 108-110.

D. Isherwood, "Geoscience Data Base Handbook for Modeling a Nuclear Waste Repository," US Nuclear Regulatery Commission report NUREG/CR-0912 (Januar.y 1981).

G. H. Jenks, "Effects of Gaseous Radioactive Nuclides on the Design and Operation of Repositories for Spent LWR Fuel in Rock Salt," Oak Ridge National Laboratcry report ORNL-5578 (December 1979).

J. K. Johnstone and K. Wolfsberg. "Evaluation of Tuff as a Medium for a Nuclear Waste Repository: Interim Status Report on the Properties of Tuff," Sandia National Laboratories report SAND-80-1464 (July 1980).

M. R. Kasper, Jr., "Future Tests at the Near-Surface Test Facility," in Basalt Waste Isolation Project Annual Report-FY 1980, Rockwell Hanford Operations report RHO-BWI-80-100 (November 1980), pp. V-35-V-37.

Y. B. Katayama, "Spent LWR Fuel Leach Tests," Pacific Northwest Laboratory report PNL-2982 (April 1979).

Y. B. Katayama, D. J. Bradley, and C. O. Harvey, "Status Report on LWR Spent-Fuel Leach Tests,"
Pacific Northwest Laboratory report PNL-3473 (November 1980).

K. Kim, "Rock Mechanics Field Test Results to Date," in Basalt Waste Isolation Project Annual ReportFY1980. Rockwell Hanford Operations report RHO-BWI-80-100 (November 1980; pp. V-26-V-j4.

S. Komarneni. B. E. Scheet, G. J. McCarthy, and W. E. Coons, "Hydrothermal Interactions of Cesium and Strontium Phases from Spent Unreprocessed Fuel with Basalt Phases and Basalt," Rockwell Hanford Operations report RHO-BWI-C-70 (March 1980).

S. T. Kosiewicz and A. Zerwekh, "Studies of Transuranic Waste Storage Under Conditions Expected in the Waste Isolation Pilot Plant (WIPP), June 15-September 30, 1979," Los Alamos Scientific Laboratory report LA-8106-PR (April 1980).

C. W. Kreitler, "Evaluation of East Texas Interior Salt Domes," in Proceedings of the National Waste Terminal Storage Program Information Meeting, Columbus. Ohio. October 30-November 1, 1979, pp. 84-85.

V. F. Likar, "Acceptance Criteria 'sr Contact-Handled and Remote-Handled Defense Transuranic Waste for WIPP," R. G. Post, Ed.,Proceedings of Waste Management '81. American Nuclear Society Topica' Meeting. Tucson. Arizona, February 23-26, 1981, pp. 375-382.

R. C. Lincoln, “The Nevada Nuclear Waste Storage Investigations," in Proceedirgs of the National Waste Terminal Storage Program Information Meeting. Columbus. Ohio. October 30-November I, 1979, pp. 13-15.

P. E. Long, "Lithologic Studies of Grande Ronde Basalt," In Basalt Waste Isolation Project Annual Report-FY I980. Rockwell Hanford Operations report RHO-BWI-80-100 (November 1980), pp. II-17-II-21.

J. F. Marron, "Exploratory Shaft Test Facility Preconceptual Design," in Basalt Waste Isolation Project Annual Report-FY 1980, Rock well Hanford Operations report RHO-BWI-80-100 (November 1980). pp. VI-32-VI-36.

W. C. McClain and R. L. Bradshaw, "Underground Waste Disposal Systems," in SME Mining Engineering 
Handbook, A. B. Cummins and 1. A. Given, Eds., Society of Mining Engineers of the American Institute of Mining, Metallurgical. and Petroleum Engineers. Inc.. New York, 1973, pp. 21-108 to 21-112.

K. B. McKinley, J. W. Cannon, R. L. Marsden, and H. A. Worle, "SPI Project Criticality Task Force Initial Review and Assessment," Edgerton, Germeshausen \& Grier report EGG-2017 (March 1980).

C. W. Meyers, S. M. Price. J. A. Caggiano, M. P. Cochran, W. J. Czimer, N. J. Davidson, R. C. Edwards. K. R. Fecht, G. E. Holmes, M. G. Iones, J. R. Kunk. R. D. Landon, R. K. Ledgerwood, J. T. Tillie, P. E. Long. T. H. Mitchell, E. H. Price. S. P. Reidel, and A. M. Tallman. "Geologic Studies of the Columbia Plateau; A Status Report." Rockwell Hanford Operations report RHO-BWI-ST-4 (October 1979).

C. W. Meyers, "Bedruck Geology and Repository Siting Studies, Cold Creek Syncline Area, Pasco Basin, Washington," in Basalt Waste Isolation Project Annual Report-FY 1980, Rockwell Hanford Operations report RHO-BWI-80-100 (November 1980), pp. II-26-II-3I.

J. G. Moore, "Testing Procedures and Initial Results from Studies on the Effect of Fly Ash and Salt in Mortars." in Proceedings of the National Waste Terminal Storage Program Information Meeting. Columbus. Ohio, Octubar 30-November 1, 1979, pp. 141-142.

J. G. Moore, G. C. Rogers, S. Katz, M. L. Morgan, and E. Newman, "FUETAP Concretes, Tailored Autoclaved Concretes for the Fixation of Radioactive Wastes." $R$. G. Post, Ed., in Proceedings of Waste Management '81, American Nuclear Society Topica! Meeting. Tucson. Arizona, February 23-26, 1981, pp. 267-276.

G. W. Murrie and T. M. Gates, "Geologir, Evaluation of Crystalline Intrusives and Selection of Candidate Areas for Detailed Investigations," in Proceedings of the National Waste Terminal Storage Program Information Meeting, Columbus, Ohio, October 30-November 1, 1979, pp. 88-90.

NAS, "The Disposal of Radioactive Waste on Land," National Academy of Sciences-National Research Council, Washington, DC (1957).
W. E. Newcomb and D. A. Waite, "Development of NWTS Program Site Qualification Criteria," in Proceedings of the National Waste Terminal Storage Program Information Meeting, Columbus, Ohio, October 30-Novembei 1. 1979, p. 63.

S. E. Norris. "Summary of Studies of Deep Formational Water Associated with the Salina Group, Ohio and New York." in Proceedings of the National Waste Terminal Storage Program Information Meeting. Columbus. Ohio, October 30-No: 4 mber 1. 1979, pp. 67-70.

Nucleonics Week. Januiry 29. 1981. pp. 10-11.

ONW1-33(2). "NWTS Criteria for the Disposal of Nuclear Wastes: Site Qualification Criteria." Offict of Nuclear Waste Management. Batielle Memorial Institute. Columbus. Ohic (1980).

J. E. O'Rourke. "Preconceptual Design of a Borehole Plugging System in a Repository in Basalt," in Basait Waste Isolation Pluject Annual Report-FY 1980," Rockwell Hariord Operations repórt RHO-BWI-80-100 (November 1080), pp. VI-46-VI-4 :

P. F. Patchick. -The Suitability of Palestine Salt Dome, Anderson Co.. Texas for Disposal of High-Level Radioactive Waste." Office of Nuclear Waste Isolation report ONWI-74 (January 1980).

J. H. Peck. D. S. Pierce. and L. W. Picking, "Geology and Hydrogeologic Modeling in the Salina Basin, New York and Ohio." in Proceedings of the National Waste Termina! Storage Program Information Meeting, Colun?. bus, Ohio, October 30-November 1, 1979, pp. 64-66.

D. W. Powers. S. J. Lambert. S. Shaffer. L. R. Hill, and W. D. Weart. "Geological Characterization Report, Waste Isolation Pilot Plant (WIPP) Site. Southeastern New Mexico." Sandia National Laboratory report SAND-78-1596 (Augu.: 1978).

S. M. Price. "Geology of the Columbia Plateau," in Basalt Waste Isolation Project Annual Report-FY 1980 , Rockwell Hanford Operations report RHO-BW1-80-100 (November 1980), pp. 11-5-11-12. 
J. R. Raymond, F. W. Bond, C. R. Cole, R. W. Nelson, A. E. Reisenauer, and J. F. Washburn. "Test Case Release Consequence Analysis for a Spent Fuel Repository in Bedded Salt," Pacific Northwest Laboratory report PNL-2782 (January 1980).

R. A. Robinson, "Overview of NWTS In Silu Test Programs," in Proceedings of the National Waste Terminal Storage Progran Information Meeting, Columbus, Ohio, October 30-November 1. 1979, pp. 93-94.

D. M. Roy, "Geochemical Factors in Borehole/Shaft Plug Longevity," in Proceedings of the National Waste Terminal Storage Program Information Meeting, Columbus, Ohio, October 30-November 1, 1979, pp. 142-147.

P. F. Salter and L. L. Ames, "An Overview of Sorption Studies," in Basalt Waste Isolation Project Annual Report-FY 1980, Rockwell Hanford Operations report RHO-BWI-80-100 (November 1980), pp. IV-28IV-34.

B. K. Schroeder, "Nuclear Waste Testing at the Near-Surface Test Facility," in Basalt Waste Isolation Project Annual Report-FY 1980, Rockwell Hanford Operations report RHO-BWI-80-100 (November 1980), pp. V-38-V-40.

R. J. Serne and J. F. Relyea, "Status Report of Sorption-Desorption Phenomena," in Proceedings of the National Waste Terminal Storage Program Information Meeting, Columbus, Ohio, October 30-November 1 , 1979, pp. 49-52.

A. J. Shor, C. F. Baes, Jr., and C. Canonico, "Studies of the Consolidation of Salt in Brine," in Proceedings of the National Waste Terminal Storage Program Information Meeting, Columbus, Ohio, October 30-November 1, 1979, pp. 55-5.

C. A. Spiers, "Regional Groundwater Hydrology of the Mississippi Salt-Dome Basin in Relation to the Storage of Nuclear Wastes," in Proceedings of the National Waste Terminal Storage Program Information Meeting, Columbus, Ohio, October 30-November 1, 1979, p. 86.

M. J. Steindler, "Chemical Engineering Divisюn, Fuel Cycle Programs Quarterly Progress ReporiOctober-December 1978," Argonne National Laboratory report ANL-79-28 (1980a).
M. J. Steindler, "Chemical Engineering Division Fuel Cycle Programs Quarterly Progress ReportJanuary-March 1979," Argonne National Laboratory report ANL-79-45 (1980b).

J. A. Stottlemyre, R. W. Wallace, G. L. Benson, and J. T. Zellmer, "Perspectives on the Geological and Hydrological Aspects of Long-Term Release Scenario Analyses," Pacific Northwest Laboratory report PNL-2928 (June 1980).

L. S. Tcgue, "Secondary Minerals Found in Cores DC2 Al and DC2 A2 Taken from the Grande Ronde Basalt Formation, Pasco Basin, Washington," Lawrence Berkeley Laboratory report LBL-10387 (January 1980).

D. A. Turner, "Summary of Fiscal Year 1980 Repository Design Activities," in Basalt Waste Isolation Project Annual Report-FY 1980, Rockwell Hanford Operations report RHO-BWI-80-100 (November 1980). pp. VI-1-VI-7.

L. D. Tyler and J. L. Krumhansl, "Conasauga Near-Surface Heater Experiment: Results and Implications," in Proceedings of the National Waste Terminal Storage Program Information Meeting, Columbus, Ohio. October 30-November 1, 1979, pp. 113-115.

E. N. Vine, R. D. Aguilar. B. P. Bayhurst, W. R. Daniels. S. J. DeVilliers, B. R. Erdal, F. O. Lawrence, S. Maestas, P. Q. Oliver, J. L. Thompson, and K. Wolfsberg. "Sorption-Desorption Studies on Tuff: II. A Continuation of Studies with Samples from Jackass Flats, Nevada and Initial Studies with Samples from Yucca Mountain Nevada," Los Alamos ؟ :ientific Laboratory report LA-81 10-MS (January 1980).

C. E. Weaver, "Geothermometry and Diagenetic Studies of Shales," in Proceedings of the National Waste Terminal Storage Program Information Meeting, Columbus, Ohio, October 30-November !, 1979, pp. 27-28.

G. G. Wicks, "Borosilicate Glass as a Matrix for Immobilization of SRP High-Level Waste," in Waste Management '81. R. G. Post, Ed., Proceedings of American Nuclear Society Topical Meeting, Tucson, Arizona. February 23-26. 19.81, pp. 321-335. 
P. A. Witherspoon, N. G. W. Cook, and J. E. Gale, "Geologic Storage of Radioactive Waste: Field Studies in Sweden," Science 211, 894-900 (1981).

K. Wolfsberg, B. P. Bayhurst, B. M. Crowe, W. R. Daniels, B. R. Erdal, F. O. Lawrence, A. E. Norris, and J. R. Smyth, "Sorption-Desorption Studies on Tuff: I. Initial Studies with Samples from the J-13 Drill Site,
Jackass Flats. Nevada." Los Alamos Scientific Laboratory report LA-7480-MS (April 1979).

K. Wolfsberg, "Sorption-Desorption Studies of Nevada Test Site Alluvium and Leaching Studies of Nuclear Test Debris," Los Alamos Scientific Laboratory report' LA-7216-MS (April 1978). 
Princed in the United Staves of Amerix Avilable from

Nxional Tectricel Information Service

US Depertmem of Commeree

5265 Pont Royel Roed Springadd. VA $2216 t$

Microficte (AO1)

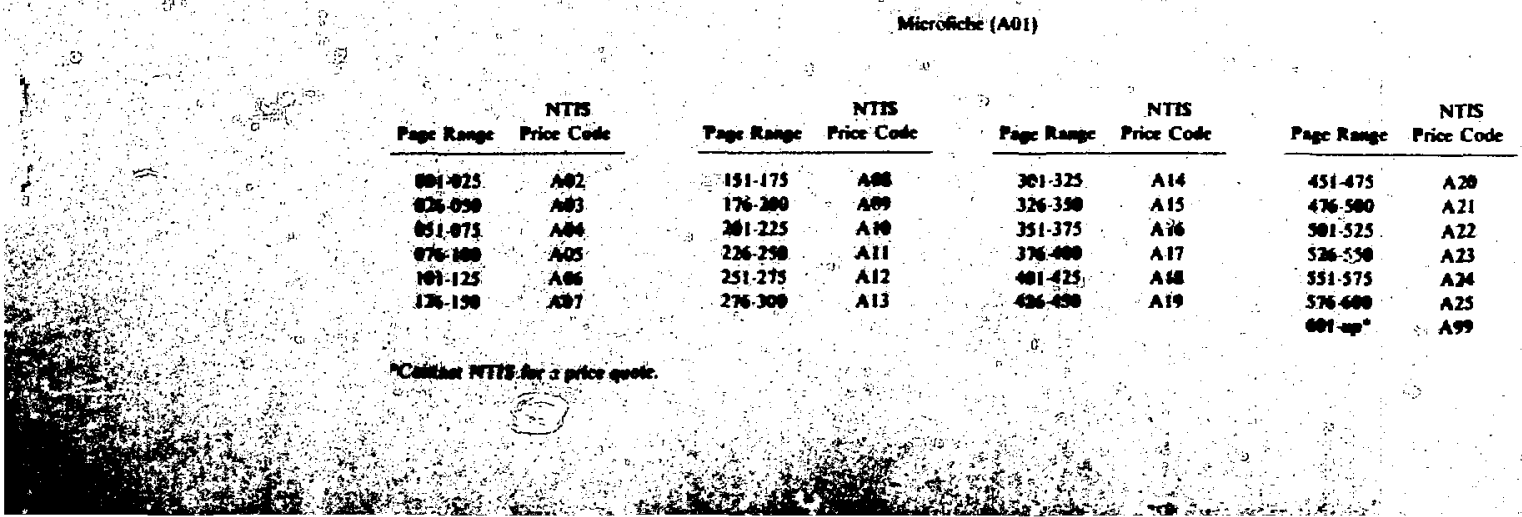
A20

A21

23

A2s 